\title{
Medicinal Plants Used in Traditional Management of Cancer in Uganda: A Review of Ethnobotanical Surveys, Phytochemistry, and Anticancer Studies
}

\author{
Timothy Omara ${ }^{1},{ }^{1,2,3}$ Ambrose K. Kiprop, ${ }^{1,3}$ Rose C. Ramkat, ${ }^{3,4}$ Jackson Cherutoi, ${ }^{1}$ \\ Sarah Kagoya $\mathbb{D}^{\mathbb{D}}{ }^{5,6}$ Decrah Moraa Nyangena $\mathbb{D}^{1,3}$ Tsedey Azeze Tebo, ${ }^{7}$ \\ Papias Nteziyaremye, ${ }^{1,3}$ Lucy Nyambura Karanja ${ }^{1},{ }^{1,3}$ Abigael Jepchirchir, ${ }^{1,3}$ \\ Alfayo Maiyo, ${ }^{1,3}$ Betty Jematia Kiptui,, ${ }^{1,3}$ Immaculate Mbabazi, ${ }^{1,3}$ \\ Caroline Kiwanuka Nakiguli $\mathbb{D}^{1,3,8}$ Brenda Victoria Nakabuye $\mathbb{D}^{1,},{ }^{9,10}$ \\ and Margaret Chepkemoi Koske $\mathbb{D}^{1,3,11}$
}

\footnotetext{
${ }^{1}$ Department of Chemistry and Biochemistry, School of Biological and Physical Sciences, Moi University, Uasin Gishu County, P.O. Box 3900-30100, Eldoret, Kenya

${ }^{2}$ Department of Quality Control and Quality Assurance, Product Development Directory, AgroWays Uganda Limited, Plot 34-60, Kyabazinga Way, P. O. Box 1924, Jinja, Uganda

${ }^{3}$ Africa Center of Excellence II in Phytochemicals, Textiles and Renewable Energy (ACE II PTRE), Moi University, Uasin Gishu County, P.O. Box 3900-30100, Eldoret, Kenya

${ }^{4}$ Department of Biological Sciences, School of Biological and Physical Sciences, Moi University, Uasin Gishu County, P.O. Box 3900-30100, Eldoret, Kenya

${ }^{5}$ Department of Chemistry, Faculty of Science, Kyambogo University, P.O. Box 1, Kyambogo, Kampala, Uganda

${ }^{6}$ Department of Quality Control and Quality Assurance, Product Development Directory, Sweets and Confectionaries Section, Kakira Sugar Limited, P.O. Box 121, Jinja, Uganda

${ }^{7}$ Southern Agricultural Research Institute (SARI), Hawassa Agricultural Research Center, P.O. Box 2126, Hawassa, Ethiopia

${ }^{8}$ Chemistry Department, Faculty of Science, Mbarara University of Science and Technology, P.O. Box 1410, Mbarara, Uganda

${ }^{9}$ Department of Food Processing Technology, Faculty of Science, Kyambogo University, P.O. Box 1, Kyambogo, Kampala, Uganda

${ }^{10}$ Department of Quality Control and Quality Assurance, Leading Distillers Uganda Limited, P.O. Box 12369, Kampala, Uganda

${ }^{11}$ Department of Chemistry, Faculty of Science, Egerton University, P.O. Box 536-20115, Njoro, Kenya
}

Correspondence should be addressed to Timothy Omara; prof.timo2018@gmail.com

Received 29 December 2019; Accepted 18 February 2020; Published 16 March 2020

Academic Editor: Konrad Urech

Copyright (c) 2020 Timothy Omara et al. This is an open access article distributed under the Creative Commons Attribution License, which permits unrestricted use, distribution, and reproduction in any medium, provided the original work is properly cited.

The burden of neoplastic diseases is a significant global health challenge accounting for thousands of deaths. In Uganda, about 32,617 cancer cases were reported in 2018, accompanied by 21,829 deaths. In a view to identify some potential anticancer plant candidates for possible drug development, the current study was designed to compile the inventory of plants with reported anticancer activity used in rural Uganda and the evidences supporting their use in cancer therapy. An electronic survey in multidisciplinary databases revealed that 29 plant species belonging to 28 genera distributed among 24 families have been reported to be used in the management of cancer in Uganda. Anticancer plants were majorly from the families Bignoniaceae (7\%), Caricaceae (7\%), Fabaceae (7\%), Moraceae (7\%), and Rutaceae (7\%). Most species occur in the wild (52\%), though some are cultivated $(48 \%)$. The growth habit of the plants is as trees $(55 \%)$ or herbs (45\%). Anticancer extracts are usually prepared from leaves $(29 \%)$, bark $(24 \%)$, roots $(21 \%)$, and fruits $(13 \%)$ through decoctions $(53 \%)$, as food spices (23\%) or pounded to produce ointments that are applied topically (10\%). Prunus africana (Hook.f.) Kalkman, Opuntia species, Albizia coriaria (Welw. ex Oliver), Daucus carota L., Cyperus alatus (Nees) F. Muell., Markhamia lutea (Benth.) K. Schum., and Oxalis corniculata L. were the most frequently encountered species. As per global reports, Allium sativum L., Annona muricata L., Carica papaya L., Moringa 
oleifera Lam., Opuntia species, Prunus africana (Hook.f.) Kalkman, and Catharanthus roseus (L.) G. Don. are the most studied species, with the latter having vincristine and vinblastine anticancer drugs developed from it. Prostate, cervical, breast, and skin cancers are the top traditionally treated malignancies. There is a need to isolate and evaluate the anticancer potential of the bioactive compounds in the unstudied claimed plants, such as Cyperus alatus (Nees) F. Muell., Ficus dawei Hutch., Ficus natalensis Hochst., and Lovoa trichilioides Harms, and elucidate their mechanism of anticancer activity.

\section{Introduction}

Cancer ascribes a collection of diseases triggered by the uncontrolled proliferation of malignant cells. It is a global health burden that has left anintolerable death toll worldwide. Conservative estimates indicate that cancer (of the liver, breasts, lungs, cervix uteri, stomach, and colorectal) causes about $13 \%$ of annual deaths globally [1]. In Uganda, there have been reports on cancer cases, though collected data are not usually coherent [2]. The commonest types of cancer encountered in Uganda include cervical, prostate, breast, lung, and skin cancers, Kaposi sarcoma, Burkitt's lymphoma, and cancer of the bone, eye, colon, and blood (leukemia) [3]. Between 1952 and 1953, 796 cases of cancer were reported in Uganda, 15 of which were stage IV cases of cancer of the cervix uteri [4]. The 1990s recorded Kaposi sarcoma, prostate, and oesophageal cancers among men and Kaposi sarcoma, cervical, and breast cancers among women as the most prevalent cancers in Uganda [5].

The eruption of the ill-fated virus (HIV) and the AIDS epidemic led to an unprecedented increase in the incidences of Kaposi sarcoma, squamous cell carcinoma of the conjunctiva, and non-Hodgkin's lymphoma in the penultimate year [6]. Cervical cancer, the fourth most prevalent cancer globally, subsequently registered an alarming relative frequency in Uganda, with 3, 915 new cases and 2, 275 annual deaths reported $[7,8]$. The situation is complicated by the fact that very few (averagely less than $10 \%$ of the 10.22 million susceptible Ugandan females) have been screened for cervical cancer [7, 9]. Reluctancy to screen, stigma, lack of awareness, chronic poverty, and inadequate medical services are largely responsible for the magnitude of the cancer epidemic in Uganda [9-11]. Thus, most cancer cases registered in hospitals are usually in their advanced stages that cannot be treated optimistically $[12,13]$.

Cancer trends for two decades (1991-2010) in the Kampala cancer registry have indicated that there has been an increase in cancer cases, peculiarly for breast cancer and prostate cancer in women and men, respectively [14]. On the other hand, the incidence of the oesophagus, liver, and large bowel (colon, rectum, and anus) cancers has remained relatively constant [14]. According to a recent report based on Gulu and Kampala cancer registries [15], 32,617 cancer cases were registered in the country in 2018 and about 21,829 of these victims succumbed to death. In Uganda, the survival of cancer patients is alarmingly deplorable in comparison to other non-African third world nations $[2,16]$. The risk factors cited for the high cancer incidences in Uganda include acquisition from family lines, hormonal imbalances, consumption of mycotoxin (aflatoxin) contaminated foods, exposure to chemicals, irradiation, viruses, and bacteria $[3,17-19]$.
Conventional therapies for the management of cancer have several side effects due to their lack of specificity and are limited in rural settings [20]. Further, the sturdy resistance of cancerous cells to cytotoxic and antineoplastic drugs has presented a fresh challenge, giving unsatisfactory ministration outcomes and capricious resistance to antineoplastic agents $[21,22]$. Coupled with the prohibitive costs, unavailability of allopathic drugs, and chronic poverty in Uganda, there is a need to fold back on home grown solutions, exploring flora and fauna [23]. Uganda, the pearl of Africa, is part of the East African botanical block and is blessed with over 6,000 plant species [24, 25]. Plants are regaining shape and emerging as an integral part of the ethnomedical approach for the management of diseases in Uganda [26]. The most cathartically notable anticancer botanical species in Uganda are Prunus africana (Hook.f.) Kalkman and the periwinkle plant (Catharanthus roseus (L.) G. Don) from which antitumor drugs vinblastine and vincristine have been developed [23, 27]. Over 5,000 phytochemicals such as phenolics, carotenoids, glucosinolates, terpenoids, and alkaloids from over 3,000 plant species have been reported to be key actors in cancer therapy [28-30]. In Uganda, anecdotal reports reveal that there exists a pool of plants utilized locally for the management of cancer [23]. Indeed, information on indigenous medicinal plants used for various maladies has been reported by preceding authors, but none of them scrutinized anticancer plants. This review seeks to obtain a list of medicinal plants reported by ethnobotanical surveys in Uganda as anticancer plants and identify the active phytochemicals in the claimed plants and the anticancer studies done on them as per global studies. Potential candidates from this review which are scantily studied will be investigated in penultimate studies.

\section{Methodology}

A comprehensive literature search was performed in Scopus, Web of Science Core Collection, PubMed, Science Direct, Google Scholar, and Scientific Electronic Library Online (SciELO) from August 2019 to November 2019 following procedures previously employed elsewhere [26]. The search was performed independently in all databases. The study databases included original articles published in peerreviewed journals, books, thesis, dissertations, patents, and other reports covering anticancer plants, dated until November 2019. All publishing years were considered, and articles with information on cancer or medicinal plants in Uganda were given utmost priority. Thus, references contained within the returned results were assessed concerning their inclusion in this study, and further searches were carried out at the Google search engine using more general 
search terms, to broaden the search, as follows: words cancer, plants, plant extract, vegetal, vegetal species, vegetal extract, traditional medicine, alternative medicine, complementary therapy, natural medicine, ethnopharmacology, ethnobotany, herbal medicine, herb, herbs, decoction, infusion, macerate, cancerous, hepatocellular carcinoma, carcinoma, prostate cancer, breast cancer, Kaposi sarcoma, Burkitt's lymphoma, cancer of the bone, cancer of the eye, cancer of the colon, cancer of the blood, leukemia, anticancer, cancer of the cervix uteri, lung cancer, liver cancer, skin cancer, and Uganda were used. The last search was done on $25^{\text {th }}$ November 2019. The search outputs were saved where possible on databases and the authors received notification of any new searches meeting the search criteria from Science Direct, Scopus, and Google scholar.

\section{Results and Discussion}

Only articles in English and local languages were considered. After the multidisciplinary database and Google search engine result assessments, sixteen reports of interest specifically on the subject of anticancer plants in Uganda were retrieved (Table 1). The botanical names of the plants listed were vetted in botanical databases: The Plant List [47], International Plant Names Index (IPNI) [48], NCBI taxonomy browser [49], and Tropicos [50]. Where a given species was considered as distinct species in different reports, the nomenclature as per the botanical databases above took precedence in the review. The botanical families used, the plant local names (Lango, Ateso, Luganda, Rukiga, Rutoro, Lusoga, Lugisu, Ngakarimojong, and Lugbara), the life forms, part(s) used, conservation status, preparation and administration mode, and the districts where the plants were reported are captured (Table 1). On anticancer potential, species studied as per global reports, the active phytochemicals reported and tested with positive results in the plant species identified by this review are reported (Table 2; Figure 1). A brief review of other ethnomedical uses of the reported species as per Ugandan and global studies is also presented (Table 3).

3.1. Traditional Concept of Cancer in Uganda. From the electronic survey, it is clear that local communities in Uganda have some information about cancer. Not all Ugandans are fully aware of cancer because most information on it is disseminated through television and radio stations which not all have access to. Another striking challenge is that there is no word for cancer in any of the Ugandan local languages. Thus, many ignore cancer because it is not anywhere recited as a health problem in their local vocabulary [16]. To many, being diagnosed with any type of cancer is equated to receiving a death sentence [234]. Some believe that conventional treatments usually cause cancer to spread, fastening the death of victims [16]. In addition, due to the ever-changing landscape of available treatment options, most patients believe that cancer can only be cured using herbal medicine and the best way to deal with cancers is through prevention [23]. Many Ugandans assume that herbal products are safer to use than allopathic drugs. In Northern Uganda, the use of shea (Vitellaria nilotica) butter, simsim (Sesame indicum L.), and groundnut (Arachis hypogea L.) pastes as substitutes for refined cooking oil and vaseline with the belief that the latter are carcinogenic is known. Unfortunately, recent reports have pointed out that some of these food items are contaminated with mycotoxins, particularly aflatoxins which are potential carcinogens $[19,235]$.

3.2. Anticancer Plants Used in Local Communities of Uganda. Cancer chemoprevention which involves the inhibition or reversion of cancer through the administration of natural or synthetic agents has gained a wider audience in Uganda. Chemopreventive agents may inhibit cancer development either by limiting exposure to carcinogens (carcinogen formation inhibitors and blocking agents) or by decreasing tumor promotion or progression stages (suppressing agents) [236]. Many compounds from medicinal or dietary plants have been reported as chemopreventive agents capable of inhibiting DNA damage and retarding or reversing carcinogenesis in in vitro and in vivo bioassays [237].

From our survey, 29 plant species from 28 genera belonging to 24 botanical families claimed as anticancer plants in Uganda have been reported (Table 1). The most cited families were Bignoniaceae (7\%), Caricaceae (7\%), Fabaceae (7\%), Moraceae (7\%), and Rutaceae (7\%). Most families encountered in this study have reported use in the traditional management of cancer in other countries across the globe. For example, Apocynaceae, Asteraceae, Bignoniaceae, Caricaceae, Fabaceae, Malvaceae, Meliaceae, Moraceae, Rutaceae, Sapindaceae, and Solanaceae were cited in Kenya [170], Ethiopia [238], Tanzania [97], and Near East (Arabian Peninsula, Egypt, Iraq, Iran, Israel, Jordan, Lebanon, Palestinian territories, Syria, and Turkey) [239], Lamiaceae in Morocco [240], and Apocynaceae, Meliaceae, and Malvaceae in Sri Lanka [241].

In addition, some of the plant species recapitulated have been documented in the treatment of cancer globally; for example; Carica papaya L., Catharanthus roseus (L.) G. Don, and Prunus africana (Hook.f.) Kalkman were reported to be used for traditional treatment of cervical, colorectal, prostate, and breast cancers $[114,170,242]$ while Albizia coriaria Welw. ex Oliver, Capsicum frutescens L., and Kigelia africana (Lam.) Benth. has been reported for the treatment of squamous cell carcinoma, throat, and breast cancers in Kenya [170]. Zanthoxylum chalybeum Engl. is used in Ethiopia and Tanzania for the treatment of breast and cervical cancers [97, 243], Blighia unijugata Baker is used for the treatment of breast and cervical cancers in Tanzania [97], while Cymbopogon citratus (DC.) Stapf is used against colorectal cancer in Kenya [170]. Interestingly, some of these plants are consumed as food spices; for example, Cymbopogon citratus (DC.) Stapf is used by most communities in Northern Uganda who cannot afford tea (Camellia sinensis (L.) Kuntze) leaves, and Beta vulgaris L. and Daucus carota L. are common ingredients in Ugandan culinary recipes [93]. Indeed, epidemiological studies have supported that dietary 
TABLE 1: Plants used in the management of cancer in rural Uganda as per reports of ethnobotanical surveys.

\begin{tabular}{|c|c|c|c|c|c|c|c|c|c|}
\hline Plant family & $\begin{array}{l}\text { Local } \\
\text { name }\end{array}$ & $\begin{array}{l}\text { Botanical } \\
\text { name }\end{array}$ & $\begin{array}{l}\text { Part } \\
\text { used }\end{array}$ & $\begin{array}{l}\text { Life } \\
\text { form }\end{array}$ & $\begin{array}{c}\text { Conservation } \\
\text { status }\end{array}$ & $\begin{array}{c}\text { Mode of } \\
\text { preparation } \\
\text { (administration) }\end{array}$ & $\begin{array}{l}\text { Cancer } \\
\text { treated }\end{array}$ & $\begin{array}{l}\text { District } \\
\text { (s) }\end{array}$ & $\begin{array}{l}\text { Author } \\
\text { (s) }\end{array}$ \\
\hline Amaranthaceae & $\begin{array}{l}\text { Beetroot (Eng), } \\
\text { no local name }\end{array}$ & Beta vulgaris $\mathrm{L}$. & $\mathrm{Blb}$ & $\mathrm{H}$ & $\mathrm{C}, \mathrm{NE}$ & $\begin{array}{l}\text { Eat beetroot/ } \\
\text { prepare juice } \\
\text { and drink }\end{array}$ & $\begin{array}{l}\text { Blood } \\
\text { cancer }\end{array}$ & $\begin{array}{c}\text { Kampala, } \\
\text { not } \\
\text { specified }\end{array}$ & {$[31,32]$} \\
\hline Amaryllidaceae & $\begin{array}{c}\text { Garlic }(E n g), \\
\text { katungulusumu } \\
(L u g)\end{array}$ & $\begin{array}{l}\text { Allium } \\
\text { sativum } \mathrm{L} .\end{array}$ & $\mathrm{Blb}$ & $\mathrm{H}$ & $\mathrm{C}, \mathrm{NE}$ & $\begin{array}{l}\text { Chew/eat } \\
\text { regularly or put } \\
\text { in food }\end{array}$ & $\begin{array}{l}\text { Lung } \\
\text { cancer }\end{array}$ & Kampala & {$[31]$} \\
\hline Annonaceae & $\begin{array}{l}\text { Kitafeeri (Lug) } \\
\text { Obwolo (Lang) }\end{array}$ & $\begin{array}{c}\text { Annona } \\
\text { muricata L. }\end{array}$ & $\begin{array}{c}\mathrm{R}, \mathrm{L} \\
\mathrm{F}\end{array}$ & $\mathrm{T}$ & $\mathrm{C}, \mathrm{NE}$ & $\begin{array}{l}\text { Decoction } \\
\text { drunk }\end{array}$ & $\begin{array}{c}\text { Not } \\
\text { specified }\end{array}$ & NS & {$[33]$} \\
\hline Apiaceae & $\begin{array}{c}\text { Carrot }(E n g), \text { no } \\
\text { local name }\end{array}$ & $\begin{array}{c}\text { Daucus } \\
\text { carota L. }\end{array}$ & $\mathrm{R}$ & $\mathrm{H}$ & $\mathrm{C}, \mathrm{NE}$ & $\begin{array}{l}\text { Eat raw roots } \\
\text { regularly; used } \\
\text { with beetroot }\end{array}$ & $\begin{array}{l}\text { Blood } \\
\text { cancer }\end{array}$ & $\begin{array}{l}\text { Wakiso, } \\
\text { Kampala }\end{array}$ & {$[31,34]$} \\
\hline Apocynaceae & Sekagya $(L u g)$ & $\begin{array}{l}\text { Catharanthus } \\
\text { roseus (L.) G. } \\
\text { Don }\end{array}$ & $\mathrm{F}$ & $\mathrm{H}$ & $\mathrm{C}, \mathrm{NE}$ & Not specified & $\begin{array}{c}\text { Not } \\
\text { specified }\end{array}$ & Kampala & {$[31]$} \\
\hline Asteraceae & $\begin{array}{c}\text { Artemesia }(E n g) \\
\text { no local name }\end{array}$ & $\begin{array}{l}\text { Artemisia } \\
\text { annua } L .\end{array}$ & $\mathrm{L}$ & $\mathrm{H}$ & $\mathrm{W}, \mathrm{NK}$ & $\begin{array}{l}\text { Infusion with } \\
\text { rock salt } \\
\text { Crushed in }\end{array}$ & $\begin{array}{c}\text { Not } \\
\text { specified }\end{array}$ & NS & {$[33]$} \\
\hline Bignoniaceae & $\begin{array}{c}\text { Yago (Lang, } \\
\text { Acholi), Edodoi } \\
\text { (Ateso), Sifungu, } \\
\text { Omusa (Lug), } \\
\text { Naizungwe (Lus) }\end{array}$ & $\begin{array}{l}\text { Kigelia } \\
\text { africana Lam. } \\
\text { Benth. }\end{array}$ & $\mathrm{R}, \mathrm{B}$ & $\mathrm{T}$ & $\mathrm{W}, \mathrm{NK}$ & $\begin{array}{l}\text { water to make a } \\
\text { concoction; } 1-2 \\
\text { tablespoonfuls } \\
\text { of juice taken } \\
\text { orally twice a } \\
\text { day }\end{array}$ & $\begin{array}{c}\text { Not } \\
\text { specified }\end{array}$ & $\begin{array}{l}\text { Tororo/ } \\
\text { Mbale }\end{array}$ & {$[35,36]$} \\
\hline Bignoniaceae & $\begin{array}{c}\text { Sambya (Lug), } \\
\text { Lusambya }(L u s) \text {, } \\
\text { Lusoola }(G i s), \\
\text { Musambia }(R u t, \\
\text { Ruk) }\end{array}$ & $\begin{array}{l}\text { Markhamia } \\
\text { lutea (Benth.) } \\
\text { K. Schum. }\end{array}$ & $\mathrm{F}$ & $\mathrm{T}$ & $\mathrm{W}, \mathrm{NK}$ & Not specified & $\begin{array}{c}\text { Not } \\
\text { specified }\end{array}$ & $\begin{array}{c}\text { Not } \\
\text { specified }\end{array}$ & {$[37,38]$} \\
\hline Burseraceae & $\begin{array}{c}\text { Mwafu }(L u g), \\
\text { Mubafu }(L u s, \\
\text { Rut })\end{array}$ & $\begin{array}{c}\text { Canarium } \\
\text { schweinfurthii } \\
\text { Engl. }\end{array}$ & $\mathrm{F}$ & $\mathrm{T}$ & $\mathrm{C}, \mathrm{NE}$ & Eat fruits & $\begin{array}{c}\text { Not } \\
\text { specified }\end{array}$ & $\begin{array}{c}\text { Not } \\
\text { specified }\end{array}$ & [39] \\
\hline Cactaceae & $\begin{array}{l}\text { Prickly pear } \\
\text { cactus (Eng) }\end{array}$ & $\begin{array}{l}\text { Opuntia } \\
\text { species* }\end{array}$ & $\mathrm{L}$ & $\mathrm{H}$ & $\mathrm{C}, \mathrm{NE}$ & $\begin{array}{l}\text { Take the juice } \\
\text { from leaves }\end{array}$ & $\begin{array}{l}\text { Prostate, } \\
\text { stomach, } \\
\text { colon and } \\
\text { rectum } \\
\text { cancer }\end{array}$ & Kampala & {$[31,40,41]$} \\
\hline Capparaceae & $\begin{array}{l}\text { Njagga (Lug), } \\
\text { Enjaaye, Njagga } \\
\text { (Rut), Jai (Lang) }\end{array}$ & $\begin{array}{l}\text { Cannabis } \\
\text { sativa } \mathrm{L} \text {. }\end{array}$ & $\mathrm{L}$ & $\mathrm{H}$ & $\mathrm{C}, \mathrm{NE}$ & $\begin{array}{l}\text { Decoction } \\
\text { drunk }\end{array}$ & $\begin{array}{c}\text { Not } \\
\text { specified }\end{array}$ & NS & {$[33]$} \\
\hline Caricaceae & $\begin{array}{c}\text { Mapapali }(\mathrm{Lug}) \\
\text { apapalo }(\text { Lang), } \\
\text { papali (Ateso), } \\
\text { Paipai }(L g b)\end{array}$ & $\begin{array}{c}\text { Carica papaya } \\
\text { L. }\end{array}$ & $\mathrm{L}$ & $\mathrm{H}$ & $\mathrm{C}, \mathrm{NE}$ & $\begin{array}{l}\text { Decoction } \\
\text { drunk }\end{array}$ & $\begin{array}{c}\text { Not } \\
\text { specified }\end{array}$ & Pallisa & {$[42]$} \\
\hline Caricaceae & Not reported & $\begin{array}{c}\text { Euclea } \\
\text { natalensis } \\
\text { A.DC. }\end{array}$ & B & $\mathrm{T}$ & $\mathrm{W}, \mathrm{NK}$ & $\begin{array}{l}\text { Decoction } \\
\text { drunk }\end{array}$ & $\begin{array}{l}\text { Prostate } \\
\text { cancer }\end{array}$ & $\begin{array}{l}\text { Mukono/ } \\
\text { Buikwe }\end{array}$ & {$[43]$} \\
\hline Cyperaceae & Not reported & $\begin{array}{c}\text { Cyperus alatus } \\
\text { (Nees) F. } \\
\text { Muell }\end{array}$ & $\mathrm{RZ}$ & $\mathrm{H}$ & $\mathrm{W}, \mathrm{NK}$ & Not specified & $\begin{array}{c}\text { Not } \\
\text { specified }\end{array}$ & $\begin{array}{c}\text { Not } \\
\text { specified }\end{array}$ & {$[37,38]$} \\
\hline Fabaceae & $\begin{array}{c}\text { Omugavu (Lug), } \\
\text { Musiita (Lus), } \\
\text { Kiluku (Kar), } \\
\text { Itek (Lang), } \\
\text { Ober (Acholi) }\end{array}$ & $\begin{array}{c}\text { Albizia } \\
\text { coriaria } \\
\text { (Welw. Ex) } \\
\text { Oliver }\end{array}$ & B & $\mathrm{T}$ & $\mathrm{W}, \mathrm{C}, \mathrm{NE}$ & $\begin{array}{c}\text { Decoction } \\
\text { drunk/applied as } \\
\text { an ointment }\end{array}$ & $\begin{array}{c}\text { Not } \\
\text { specified }\end{array}$ & NS & [33] \\
\hline
\end{tabular}


TABle 1: Continued.

\begin{tabular}{|c|c|c|c|c|c|c|c|c|c|}
\hline Plant family & $\begin{array}{l}\text { Local } \\
\text { name }\end{array}$ & $\begin{array}{l}\text { Botanical } \\
\text { name }\end{array}$ & $\begin{array}{l}\text { Part } \\
\text { used }\end{array}$ & $\begin{array}{l}\text { Life } \\
\text { form }\end{array}$ & $\begin{array}{l}\text { Conservation } \\
\text { status }\end{array}$ & $\begin{array}{c}\text { Mode of } \\
\text { preparation } \\
\text { (administration) }\end{array}$ & $\begin{array}{l}\text { Cancer } \\
\text { treated }\end{array}$ & $\begin{array}{l}\text { District } \\
\text { (s) }\end{array}$ & $\begin{array}{l}\text { Author } \\
\text { (s) }\end{array}$ \\
\hline Fabaceae & $\begin{array}{c}\text { Jjirikiti }(\text { Lug), } \\
\text { Murinzi, Kiko } \\
\text { Omoko/Echuko, } \\
(\text { Rut/Ruk), Oluo } \\
(L g b), \text { Owila kot } \\
\text { (Lang), } \\
\text { Muyirikiti (Lus) }\end{array}$ & $\begin{array}{c}\text { Erythrina } \\
\text { abyssinica } \\
\text { Lam. ex DC. }\end{array}$ & $\mathrm{B}, \mathrm{R}$ & $\mathrm{T}$ & $\mathrm{W}, \mathrm{NK}$ & $\begin{array}{c}\text { Decoction } \\
\text { drunk }\end{array}$ & $\begin{array}{c}\text { Not } \\
\text { specified }\end{array}$ & NS & {$[33]$} \\
\hline Lamiaceae & $\begin{array}{c}\text { Mubengeya, } \\
\text { Nfulubwa, } \\
\text { Ffulubwa }(L u g)\end{array}$ & $\begin{array}{l}\text { Vitex fischeri } \\
\text { Gürke }\end{array}$ & $\mathrm{L}$ & $\mathrm{T}$ & $\mathrm{W}, \mathrm{NK}$ & $\begin{array}{l}\text { Decoction } \\
\text { drunk }\end{array}$ & $\begin{array}{c}\text { Not } \\
\text { specified }\end{array}$ & NS & {$[33]$} \\
\hline Malvaceae & $\begin{array}{c}\text { Okra (Eng), } \\
\text { Otigo (Lang), } \\
\text { Bamia (Lus) }\end{array}$ & $\begin{array}{l}\text { Abelmoschus } \\
\text { esculentus (L.) } \\
\text { Moench }\end{array}$ & $\mathrm{F}$ & $\mathrm{H}$ & $\mathrm{C}, \mathrm{NE}$ & $\begin{array}{c}\text { Eat as food or } \\
\text { add to food as a } \\
\text { spice }\end{array}$ & $\begin{array}{l}\text { Stomach, } \\
\text { rectum and } \\
\text { colon } \\
\text { cancer }\end{array}$ & Kampala & {$[31]$} \\
\hline Meliaceae & Musonko (Lug) & $\begin{array}{l}\text { Lovoa } \\
\text { trichilioides } \\
\text { Harms }\end{array}$ & $\begin{array}{l}\text { B, } \\
\text { Sd, L }\end{array}$ & $\mathrm{T}$ & $\mathrm{W}, \mathrm{E}$ & $\begin{array}{l}\text { Crushed and } \\
\text { applied as an } \\
\text { ointment }\end{array}$ & $\begin{array}{c}\text { Not } \\
\text { specified }\end{array}$ & NS & {$[33]$} \\
\hline Moraceae & Muwo (Lug) & $\begin{array}{l}\text { Ficus dawei } \\
\text { Hutch. }\end{array}$ & B & $\mathrm{T}$ & $\mathrm{W}, \mathrm{NK}$ & $\begin{array}{l}\text { Decoction } \\
\text { drunk }\end{array}$ & $\begin{array}{l}\text { Breast } \\
\text { cancer }\end{array}$ & $\begin{array}{l}\text { Mukono/ } \\
\text { Buikwe }\end{array}$ & {$[43]$} \\
\hline Moraceae & Mugaire (Lus) & $\begin{array}{c}\text { Ficus } \\
\text { natalensis } \\
\text { Hochst. }\end{array}$ & $\mathrm{R}$ & $\mathrm{T}$ & $\mathrm{W}, \mathrm{NE}$ & Not specified & $\begin{array}{l}\text { Cancerous } \\
\text { wounds }\end{array}$ & Iganga & {$[44]$} \\
\hline Moringaceae & $\begin{array}{l}\text { Moringa (Eng), } \\
\text { molinga (Lug) }\end{array}$ & $\begin{array}{c}\text { Moringa } \\
\text { oleifera Lam. }\end{array}$ & $\begin{array}{l}\text { L, R, } \\
\text { B, Sd }\end{array}$ & $\mathrm{H}$ & $\mathrm{C}, \mathrm{NE}$ & $\begin{array}{l}\text { Chew/make } \\
\text { juices }\end{array}$ & $\begin{array}{l}\text { Prostate, } \\
\text { lung, colon } \\
\text { and rectal } \\
\text { cancers }\end{array}$ & Kampala & {$[31,45]$} \\
\hline Oxalidaceae & $\begin{array}{c}\text { Kajjampuni } \\
\text { (Lug), } \\
\text { Kaanhunu (Lus), } \\
\text { Otyer (Lang) }\end{array}$ & $\begin{array}{c}\text { Oxalis } \\
\text { corniculata L. }\end{array}$ & $\mathrm{L}$ & $\mathrm{H}$ & $\mathrm{W}, \mathrm{E}$ & $\begin{array}{l}\text { Pound, dry and } \\
\text { put on the } \\
\text { wound }\end{array}$ & $\begin{array}{l}\text { Skin and } \\
\text { uterine } \\
\text { cancer }\end{array}$ & $\begin{array}{l}\text { Mukono/ } \\
\text { Buikwe, } \\
\text { Iganga }\end{array}$ & {$[43,44]$} \\
\hline Poaceae & $\begin{array}{l}\text { Akisube (Ateso), } \\
\text { Kisubi (Lug), } \\
\text { Lum cai (Lang) }\end{array}$ & $\begin{array}{l}\text { Cymbopogon } \\
\text { citratus (DC) } \\
\text { Stapf }\end{array}$ & $\mathrm{L}$ & $\mathrm{H}$ & $\mathrm{C}, \mathrm{NE}$ & $\begin{array}{l}\text { Decoction } \\
\text { drunk }\end{array}$ & $\begin{array}{c}\text { Not } \\
\text { specified }\end{array}$ & Pallisa & {$[42]$} \\
\hline Rosaceae & $\begin{array}{c}\text { African cherry } \\
\text { (Eng), } \\
\text { Ngwabuzito } \\
(\text { Lug), Ntaseesa, } \\
\text { Ngwabuzito } \\
\text { (Rut), } \\
\text { Sirumandu (Gis) }\end{array}$ & $\begin{array}{c}\text { Prunus } \\
\text { africana } \\
\text { (Hook.f.) } \\
\text { Kalkman } \\
\text { (Pygeum } \\
\text { africanum) }\end{array}$ & L, B & $\mathrm{T}$ & $\mathrm{W}, \mathrm{OD}$ & $\begin{array}{l}\text { Decoction } \\
\text { drunk/tea }\end{array}$ & $\begin{array}{l}\text { Prostate } \\
\text { cancer }\end{array}$ & $\begin{array}{c}\text { NS, Not } \\
\text { specified, } \\
\text { Mukono/ } \\
\text { Buikwe, } \\
\text { Not } \\
\text { specified }\end{array}$ & {$[23,33,43,46]$} \\
\hline Rutaceae & $\begin{array}{c}\text { Omuqugwa } \\
\text { (Ateso), } \\
\text { Amacunga } \\
\text { (Lang) }\end{array}$ & $\begin{array}{c}\text { Citrus } \\
\text { reticulata } \\
\text { Blanco, } 1837\end{array}$ & $\mathrm{R}$ & $\mathrm{T}$ & $\mathrm{C}, \mathrm{NE}$ & Not specified & $\begin{array}{c}\text { Not } \\
\text { specified }\end{array}$ & Pallisa & {$[42]$} \\
\hline Rutaceae & $\begin{array}{l}\text { Ntale ya ddungu } \\
\text { (Lug), Eusuk } \\
\text { (Ateso), } \\
\text { Agodaman } \\
\text { (Lang), Rukuts } \\
\text { (Kar), Outiku } \\
\text { (Lugb) }\end{array}$ & $\begin{array}{l}\text { Zanthoxylum } \\
\text { chalybeum } \\
\text { Engl. }\end{array}$ & $\mathrm{R}$ & $\mathrm{T}$ & $\mathrm{W}, \mathrm{NK}$ & $\begin{array}{c}\text { Pound, add } \\
\text { water \& drink }\end{array}$ & $\begin{array}{l}\text { Cervical } \\
\text { cancer }\end{array}$ & $\begin{array}{l}\text { Mukono/ } \\
\text { Buikwe }\end{array}$ & [43] \\
\hline Sapindaceae & $\begin{array}{c}\text { Mukuzanyana } \\
\text { (Lug), } \\
\text { Nkuzanyana } \\
(\text { Rut })\end{array}$ & $\begin{array}{c}\text { Blighia } \\
\text { unijugata } \\
\text { Baker }\end{array}$ & B & $\mathrm{T}$ & $\mathrm{W}, \mathrm{NK}$ & $\begin{array}{l}\text { Decoction } \\
\text { drunk }\end{array}$ & $\begin{array}{l}\text { Cervical } \\
\text { cancer }\end{array}$ & $\begin{array}{l}\text { Mukono/ } \\
\text { Buikwe }\end{array}$ & [43] \\
\hline
\end{tabular}


TABle 1: Continued.

\begin{tabular}{lccccccccc}
\hline Plant family & $\begin{array}{c}\text { Local } \\
\text { name }\end{array}$ & $\begin{array}{c}\text { Botanical } \\
\text { name }\end{array}$ & $\begin{array}{c}\text { Part } \\
\text { used }\end{array}$ & $\begin{array}{c}\text { Life } \\
\text { form }\end{array}$ & $\begin{array}{c}\text { Conservation } \\
\text { status }\end{array}$ & $\begin{array}{c}\text { Mode of } \\
\text { preparation } \\
\text { (administration) }\end{array}$ & $\begin{array}{c}\text { Cancer } \\
\text { treated }\end{array}$ & $\begin{array}{c}\text { District } \\
(\mathrm{s})\end{array}$ & $\begin{array}{c}\text { Author } \\
(\mathrm{s})\end{array}$ \\
\hline Solanaceae & $\begin{array}{c}\text { Kamulali }(\text { Lug), } \\
\text { Kamularu } \\
\text { (Lang) }\end{array}$ & $\begin{array}{c}\text { Capsicum } \\
\text { frutescens L. }\end{array}$ & F & H & W, C & Food condiment & $\begin{array}{c}\text { Prostate } \\
\text { cancer }\end{array}$ & $\begin{array}{c}\text { Mukono/ } \\
\text { Buikwe }\end{array}$ & {$[43]$} \\
\hline
\end{tabular}

Languages: Eng: English, Gis: Lugishu, Lgb: Lugbara, Lug: Luganda, Lus: Lusoga, Lang: Lango, Kar: Ngakarimojong, Rut: Rutoro, Ruk: Rukiga. Parts used: B: bark, Blb: bulb, F: fruit, L: leaf, R: root, RZ: rhizome, Sd: seed. Growth habit: H: herb, T: tree. Conservation status: C: cultivated, W: grows in the wild/forest, E: endangered, NE: not endangered, OD: out of danger, NK: not known. Districts: NS: this study was done in Arua, Dokolo, Mbale, Iganga, Bushenyi, Rakai, Luwero, and Kaabong districts of Uganda. ${ }^{*}$ Species not specified. Opuntia hybridizes readily between species.

TABLE 2: Anticancer activity of the medicinal plant species reported in Uganda as per global reports.

\begin{tabular}{lc}
\hline Plant & Active phytochemicals \\
\hline & \\
Abelmoschus & Isoquercitrin (1), quercetin (2), hyperoside (hyperin), \\
esculentus (L.) & coumarin scopoletin, and uridine [51]
\end{tabular}
Molecular targets and/or effects on cancer cells Cytotoxicity of extracts reported against breast cancer (MCF-7), hepatocellular carcinoma (HepG2), and cervical carcinoma (HeLa) cell lines [51]. Isoquercitrin inhibited urinary bladder, pancreatic, and colon cancer progress [52-54]

Moench

Extracts induced significant cell growth inhibition

$(63 \%)$ in human breast cancer (MCF-7) and skin

fibroblast (CCD-1059 sk) cells. The expression of proapoptotic caspase-3, caspase-9, and p21 genes was increased in MCF-7 cells [55]

Cytotoxicity $\left(\mathrm{IC}_{50}>500 \mu \mathrm{g} / \mathrm{ml}\right)$ against human embryonic lung fibroblast (HELF) cells [59].

Albizia coriaria (Welw. ex Oliver)

Oleanane-type saponins (coriarioside A and coriarioside B), gummiferaoside C, acacic acid glycosides, lupeol (3), lupenone, betulinic acid, acacic acid lactone, $(+)-$ catechin, and benzyl alcohol [56-58]
Coriarioside $\mathrm{A}$ and gummiferaoside $\mathrm{C}$ from root bark showed cytotoxicity against two colorectal human

cancer cells: HCT116 (with $\mathrm{IC}_{50}$ of $4.2 \mu \mathrm{M}$ for coriarioside A and $2.7 \mu \mathrm{M}$ for gummiferaoside $\mathrm{C}$ ) and HT-29 (with $\mathrm{IC}_{50} 6.7 \mu \mathrm{M}$ for coriarioside A and $7.9 \mu \mathrm{M}$ for gummiferaoside C) cell lines [56]

Extracts exhibited an antiproliferative effect on human cancer cell lines, including liver (HepG2), colon (Caco2), prostate (PC-3), and breast (MCF-7) cancer cells [61]. Extracts induced G2/M-phase cell cycle arrest in EJ bladder cancer cells [62]. DATS suppressed the proliferation of SGC-7901 gastric cancer cells [63]

SAC induced cell cycle arrest in A2780 human epithelial ovarian cancer cells [64]. S-propargyl-1-

Diallyl thiosulfinate (allicin) (4), diallyl sulfide (DAS) (5), Allium sativum L. diallyl disulfide (DADS) (6), diallyl trisulfide (DATS) (7), E-ajoene (8), Z-ajoene (9), S-allyl-cysteine (SAC) (10), and a S-allyl-cysteine sulfoxide (alliin) (11) [60] cysteine (SPRC), an analogue of SAC, reduced the proliferation of human pancreatic ductal adenocarcinoma cells and induced cell cycle arrest [65].

Garlic derived S-allylmercaptocysteine (SAMC) suppressed the proliferation of hepatocellular carcinoma cells [66]. SAMC inhibited the proliferation of human colorectal carcinoma SW620 cells [67] Allicin inhibited the proliferation of gastric adenocarcinoma cells by inducing cell cycle arrest [68]. Ajoene was shown to restrain the growth of glioblastoma multiforme cancer stem cells and human breast cancer cells [69] 
TABLE 2: Continued.

\begin{tabular}{cc}
\hline Plant & Molecular targets and/or effects on cancer cells \\
\hline & Annonaceous acetogenins exhibited antiproliferative \\
& activity against human prostate cancer PC-3 cells [70]. \\
& Fruit extracts are cytotoxic against U937 histiocytic \\
& lymphoma cell lines with $\mathrm{IC}_{50}$ of $10.5,18.2$, and $60.9 \mu \mathrm{g} /$ \\
& ml for ethyl acetate, hexane, and methanol extracts \\
& respectively [74] \\
& Annonacin caused complete suppression of $7,12-$
\end{tabular}

dimethylbenz[a] anthracene (DMBA) induced and 12-

0 - tetradecaboylphorbol-13-acetate (TPA) promoted skin tumorigenesis in mice [75]

At $0.1 \mu \mathrm{M}$, annonacin induced growth arrest and apoptosis in breast cancer (MCF-7) cells [76]

Annomuricin E was cytotoxic to HT-29 colon carcinoma and CCD841 normal colon cell lines with $\mathrm{IC}_{50}$ values of $5.72,3.49$, and $1.62 \mu \mathrm{g} / \mathrm{mL}$ for HT-29 cells at time intervals of 12,24 , and 48 hours of administration, respectively [77]

Stem extracts suppressed the expression of molecules associated with hypoxia and glycolysis in CD18/HPAF

(pancreatic) cancer cells $\left(\mathrm{IC}_{50}\right.$ of $73.0 \mu \mathrm{g} / \mathrm{mL}$ ) [78] Aqueous leaf extracts exhibited anticancer activity with $\mathrm{IC}_{50}$ values of 220,350 , and $250 \mu \mathrm{g} / \mathrm{mL}$ for breast cancer cell lines: MCF7, MDA-MB231, and 4T1, respectively [79]. Leaf extracts recorded cytotoxicity against human bladder cancer (K562) and leukemia cancer (ECV304) cell lines [80]

Annonaceous acetogenins (muricin J, muricin K, muricin

L) [70], annonacin (12), annomuricin A (13),

Annona muricata L. annomuricin $\mathrm{E}(\mathbf{1 4})$, annomuricin $\mathrm{C}$, annomutacin, gigantetronin $[71,72]$, quercetin, luteolin $3^{\prime} 7$-di-oglucoside, gallic acid, apigenin-6-c-glucoside, taxifolin (+)

Cytotoxicity recorded against Raji cells with $\mathrm{IC}_{50}$ values of 90.6, 407.2, and $260.2 \mu \mathrm{g} / \mathrm{mL}$. Cytotoxic effect of chloroform and n-hexane extracts on HeLa cell lines gave $\mathrm{IC}_{50}$ values of 127.3 and $169.2 \mu \mathrm{g} / \mathrm{mL}$, respectively [81] Leaf extracts inhibited cell proliferation in pancreatic cancer cells (capan-1) [82]

Ethanol extract of seeds showed a cytotoxic effect on MDBK and HEp-2 cells ( IC $_{50}$ values: 34.5 and $55 \mathrm{mg}$ / $\mathrm{mL}$, respectively) at $24 \mathrm{~h}$, and an $\mathrm{IC}_{50}$ value of $49.6 \times 10^{-3} \mathrm{mg} / \mathrm{mL}$ toward HEp-2 cells at $72 \mathrm{~h}$ [83] Cytotoxic against kidney epithelial (VERO), stomach cancer (C-678), and human large lung cell carcinoma

$(\mathrm{H}-460)$ cell lines with $\mathrm{IC}_{50}$ values lower than $0.00022 \mathrm{mg} / \mathrm{mL}$ for all the cell lines [84]. Cytotoxicity was reported against histiocytic lymphoma cell lines (U937), pancreatic cancer cells (FG/COLO357), breast cancer cells (MDA-MB-435S), immortalized human keratinocytes (HaCat), normal human liver cells (WRL-68), and human skin malignant melanoma (A375) [73, 78, 85-87]. In histiocytic lymphoma cell lines, the extract had an $\mathrm{IC}_{50}$ value of $7.8 \mu \mathrm{g} / \mathrm{mL}$. Toxicity toward FG/COLO357 with an $\mathrm{IC}_{50}$ value of $200 \mu \mathrm{g} / \mathrm{mL}$ [78]. Cytotoxic effect of $n$-butanolic extract of leaves against MDA-MB-435S (human breast carcinoma), HaCaT (human immortalized keratinocyte), and WRL-68 (normal human hepatic) cell lines with $\mathrm{IC}_{50}$ values of $29.2,30.1$, and $52.4 \mu \mathrm{g} / \mathrm{mL}$, respectively [73]

Ethanol extracts of leaves cytotoxic to Ehrlich Ascites carcinoma (EACC) and breast cancer (MDA and SKBR3) cell lines with $\mathrm{IC}_{50}$ values of $335.85,248.77$, and $202.33 \mu \mathrm{g} /$ $\mathrm{mL}$ [88]. Fruit extracts had substantial repression of breast cancer cells (MDA-MB-468) growth as well as selective suppression of epidermal growth factor receptor (EGFR) with $\mathrm{IC}_{50}$ of $4.8 \mu \mathrm{g} / \mathrm{mL}$ [89] 
TABle 2: Continued.

\begin{tabular}{|c|c|c|}
\hline Plant & Active phytochemicals & Molecular targets and/or effects on cancer cells \\
\hline Artemisia annua L. & $\begin{array}{c}\text { Sesquiterpene trioxane lactone (artemisinin) (15) [90], } \\
\text { Chrysosplenol D, arteannuin B, casticin, arteannuic acid, } \\
\text { or 6,7-dimethoxycoumarin [91] }\end{array}$ & $\begin{array}{l}\text { Acetonitrile extract inhibited the viability of breast } \\
\text { (MDA-MB-231 and MCF-7), pancreas (MIA PaCa-2), } \\
\text { prostate (PC-3), and non-small-cell lung cancer (A459) } \\
\text { cells. The extracts inhibited cancer cell proliferation, } \\
\text { decreased tumor growth, and induced apoptosis in vivo } \\
\text { in triple negative breast cancer (MDA-MB-231) } \\
\text { xenografts grown on the chick chorioallantoic } \\
\text { membrane (CAM) assay as well as in nude mice [91]. } \\
\text { Hydroalcoholic extract had a cytotoxic effect in a dose- } \\
\text { dependent manner against D-17 canine osteosarcoma } \\
\text { cell lines better than pure artemisinin, indicating a } \\
\text { possible synergistic effect of the phytocomplex and a } \\
\text { mechanism of action involving iron and possibly } \\
\text { ferroptosis [92] }\end{array}$ \\
\hline
\end{tabular}

The ethanolic extract exhibited significant anticancer activity against lung cancer (A549) cell line but only a slight effect against colorectal adenocarcinoma

(Caco-2) cell line at $800 \mu \mathrm{g} / \mathrm{mL}$ [94]. Cytotoxicity

Lutein, $\beta$-carotene, betalains, betaine, ferulic, caffeic, oleanolic, $p$-coumaric and syringic acids, rutin (16),

Beta vulgaris L. kaempferol (17), rhamnetin, rhamnocitrin, and astragalin $[93,94]$

against PC-3 cells led to a decrease in the growth rate of the cells ( $3.7 \%$ in 3 days) at $29 \mu \mathrm{g} / \mathrm{mL}$.

Comparative cytotoxicity tests in normal human skin (FC) and liver (HC) cell lines showed that the extracts were cytotoxic on the cells, though the activity was lower than that of doxorubicin $(8.6 \%$ compared to $100 \%$, respectively, at $29 \mu \mathrm{g} / \mathrm{mL}$ concentration in a 3-day test period) [95]

Methyl salicylate, oleic acid, 2-morpholinophenazine, octadec-9-enoic acid, 2-[(tert-butyldimethylsily)oxy]-1isopropyl-dimethyl-benzene, octadecanoic acid, 1,3-

Blighia unijugata Baker dibromo-4,5-dimethylbenzene, 3,7-dimethyl-8-oxo-5dioxa-spiro [5]-3-methyl-undecanoate, 1,2-bis(trimethylsilyl)benzene, and octadecanoic acid [96]

Cannabis sativa L. $\quad \Delta^{9}$-tetrahydrocannabinol, THC (18) [98]
Leaves and stem bark extracts had $\mathrm{LC}_{50}$ of 539.6 and $389.8 \mu \mathrm{g} / \mathrm{mL}$ in brine shrimp toxicity [97]

THC and other cannabinoids exhibited antitumor effects in animal models of cancer [99]. The acetone extract exhibited more anticancer activity against breast adenocarcinoma (MCF-7), the glioblastoma (SF-268), and the colon adenocarcinoma (HT-29) cells [100]

3a-Hydroxytirucalla-8, 24-dien-21-oic, $3 \alpha$ hydroxytirucalla-7,24-dien-21-oic and $3 \beta$-fluorotirucalla7,24-dien-21-oic acids [101], catechol (19), tyrosol,

Canarium schweinfurthii Engl. vanillic, and phloretic acids, limonene, phellandrenes, $\mathrm{p}$ hydroxybenzaldehyde, dihydroxyphenylacetic acid, $p$ hydroxybenzoic acid, dihydroxybenzoic acid, pinoresinol, secoisolariciresinol [102], schweinfurthinol, coniferaldehyde, $p$-hydroxycinnamaldehyde, ligballinol, and amentoflavone [103]
Capsaicin (20) and quercetin [105]
Cytotoxicity test on leukemia (CCRF-CEM) cells at $40 \mu \mathrm{g} / \mathrm{mL}$ showed that leaves and bark extracts induced more than $50 \%$ growth of this cell line. Fruit mesocarp oil extract and seed kernel oil extracts are expected to be vital for chemoprevention of cancers and other oxidative damage-induced diseases [104]

Aqueous fruit extracts exhibited anticancer activity (though lower than capsaicin standard) when tested against prostate (PC-3) and breast (MCF-7) cancer cell lines in vitro [105] 
TABLE 2: Continued.

Plant Active phytochemicals

Molecular targets and/or effects on cancer cells

Pure lycopene and papaya juice inhibited the viability of liver cancer (HepG2) cell line with $\mathrm{IC}_{50}$ of $22.8 \mu \mathrm{g} /$ $\mathrm{mL}$ and $20 \mathrm{mg} / \mathrm{mL}$ [108].

$n$-hexane seed extract dose-dependently inhibited superoxide generation $\left(\mathrm{IC}_{50}=10 \mu \mathrm{g} / \mathrm{mL}\right)$ and the viability of acute promyelocytic leukemia (HL-60) cells $\left(\mathrm{IC}_{50}=20 \mu \mathrm{g} / \mathrm{mL}\right)$, comparable to that of pure benzyl isothiocyanate [109]

Aqueous extract of flesh $(0.01-4 \% \mathrm{v} / \mathrm{v})$ inhibited the proliferation of breast cancer cell line (MCF-7) [110].

Ethanolic extract of the pericarp $(50-640 \mu \mathrm{g} / \mathrm{mL})$ inhibited the growth of breast cancer cell line (MCF-7) treated with sodium nitroprusside, a nitric oxide donor [111]. Breast cancer cell line (T47D) was inhibited by leaf protein fraction with $\mathrm{IC}_{50}=2.8 \mathrm{mg} / \mathrm{mL}$ ) and induced apoptosis by regulation of protein expression [112] Aqueous extracts of leaves $(1.25-27 \mathrm{mg} / \mathrm{mL})$ exhibited a concentration-dependent anticancer effect on stomach cancer cell line (AGS), pancreatic cancer cell line (Capan-1), colon cancer cell line (DLD-1), ovarian cancer cell line (Dov-13), lymphoma cell line (Karpas), breast cancer cell line (MCF-7), Neuroblastoma cell line

(T98G), uterine cancer cell line (HeLa), and T-cell

Lycopene, ferulic acid, benzyl isothiocyanate, kaempferol, Carica papaya L. quercetin, chlorogenic acid, caffeic acid, beta carotene, and $p$-coumaric acid $[106,107]$

leukemia cell line (CD26 negative or negative Jurkat)

cell lines and suppressed DNA synthesis by suppressing the incorporation of $3 \mathrm{H}$-thymidine [113]

Aqueous extract of leaves $(0.625-20 \mathrm{mg} / \mathrm{mL})$ inhibited the proliferative responses of both haematopoietic and solid tumor cell lines (T-cell lines, H9, Jurkat, Molt-4, CCRF-

CEM, and HPB-ALL), Burkitt's lymphoma cell lines

(Ramos and Raji), chronic myelogenous leukemia cell line (K562), cervical carcinoma cell line (HeLa), hepatocellular carcinoma cell lines (HepG2 and Huh-7), lung adenocarcinoma cell line (PC-14), pancreatic epithelioid carcinoma cell line (Panc-1), mesothelioma cell lines (H2452, H226, and MESO-4), plasma cell leukemia cell line (ARH77), anaplastic large cell lymphoma cell line (Karpas299), breast adenocarcinoma cell line (MCF-7), mesothelioma cell line (JMN), and pancreatic adenocarcinoma cell line (Capan-1). In peripheral blood mononuclear cells, the extract reduced the production of IL-2 and IL- 4 whereas it increased the production of Th1 types cytokines such as IL-12p40, IL-12p70, INF- $\gamma$, and TNF- $\propto$. The expression of 23 immunomodulatory genes was enhanced by the addition of papaya extract [114] Leaf juice not only exhibited a stronger cytotoxic effect on human squamous cell carcinoma (SCC25 cancer) cells but also produced a significant cancer-selective effect as shown by tests on noncancerous human keratinocyte HaCaT cells [115]

Antitumor terpenoid indole alkaloids: vincristine and vinblastine, serpentine, catharanthine, ajmalicine, akuammine, lochnerine, lochnericine, tetrahydroalstonine, $3^{\prime}, 4^{\prime}$-anhydrovinblastine, serpentine, vincaleukoblastine, leurocristine, vincaleurocristine, vincarodine, vincoline, leurocolombine, viramidine, vincathicine, vincubine, isositsirikine, vincolidine, catharanthine, vindoline, tetrahydroalstonine, vindolinine, reserpine, coronaridine, 11methoxy tabersonine, tetrahydroalstonine, vindorosidine, hydroxytyrosol, ferulic acid, chlorogenic acid, kaempferol, trisaccharides, quercetin, and petunidin 3-O-(6-O-p-
Cytotoxicity with $\mathrm{LC}_{50}$ of $6.7 \mu \mathrm{g} / \mathrm{ml}$ in brine shrimp assay $[97,118,119]$

Vindoline from leaf extracts was cytotoxic to HCT-116 colorectal carcinoma cell line at $200 \mu \mathrm{g} / \mathrm{mL}$ [120]
(L.) G. Don. 
TABLE 2: Continued.

\begin{tabular}{|c|c|c|}
\hline Plant & Active phytochemicals & Molecular targets and/or effects on cancer cells \\
\hline $\begin{array}{l}\text { Citrus reticulata } \\
\text { Blanco, } 1837\end{array}$ & $\begin{array}{l}\text { Limonin, isolimonexic acid methyl ether, ichangin, } \\
\text { deacetylnomilin, and obacunone }[121]\end{array}$ & $\begin{array}{l}\text { In vitro tumor cytotoxicity of different varieties against } \\
\text { gastric cancer cell lines (SGC-7901, BGC-823, and } \\
\text { AGS) recorded } \mathrm{IC}_{50} \text { ranging from } 20.49 \text { to } 368.40 \mu \mathrm{g} / \\
\text { mL [122]. Antiangiogenic effect was reported [123] }\end{array}$ \\
\hline $\begin{array}{l}\text { Cymbopogon citratus } \\
\text { (DC) Stapf }\end{array}$ & $\begin{array}{l}\text { Citral (neral and geranial), geraniol and } \beta \text {-myrcene, 6- } \\
\text { methyl-5-hepten-2-one, and undeca-2-one [124]. Oils } \\
\text { contain geranial, neral, myrcene, and beta-pinene [125] }\end{array}$ & $\begin{array}{c}\text { Essential oil exhibited protective action against } N \text { - } \\
\text { butyl- } N \text {-(4-hydroxibuthyl)nitrosamine-induced DNA } \\
\text { damage and a potential anticarcinogenic activity } \\
\text { against mammary carcinogenesis in } 7,12- \\
\text { dimethylbenz(a) anthracene, } 1,2 \text {-dimethylhydrazine } \\
\text { initiated female Balb/C mice [124]. In synergy with } \\
\text { Taraxacum officinale root extract induced apoptosis in } \\
\text { prostate cancer cells (DU-145 and PC-3). The lowest } \\
\text { combination dosage of taxol treatment }(0.01 \mu \mathrm{M} \text { with } \\
0.01 \mathrm{mg} / \mathrm{mL} \text { extract) showed comparable induction of } \\
\text { apoptosis to the highest individual treatment dosage of } \\
\text { taxol }(0.5 \mu \mathrm{M})[20]\end{array}$ \\
\hline
\end{tabular}

Chemopreventive against 7,12-dimethyl Benz(a) anthracene-induced squamous cell carcinoma in mice

[126]. The aqueous extract has anticancer activity

$\alpha$-Longipinene, methyl isoeugenol, elemicin, $\beta$-Selinene,

$\beta$-asarone, $\beta$-himachalene, $\beta$-bisabolene, $\alpha$-humulene, widdrol, allo-aromadendrene, $\alpha$-caryophyllene,

Daucus carota $\mathrm{L}$. $\quad \beta$-caryophyllene, caryophyllene oxide, aromadendrene

[126], 2-himachalen-6-ol, (+)-a-longipinene,

longicyclene, and $\beta$-caryophyllene [127]

against human promyelocytic leukemia HL-60 cells. Oil extract is chemopreventive against induced skin cancer [128]. Apoptosis was recorded with colon and breast human cancer cell lines; pentane oil fraction showed a cytotoxic effect on human breast adenocarcinoma cell lines MDA-MB-231 and MCF-7, causing cell cycle arrest and increased apoptosis mediated through the Erk pathway [129]

Elaeodendron Steroidal glycosides, eudesmane-type sesquiterpenoid, buchananii (Loes.) and dammarane triterpenoids: elabunin (21) [130-132]

Erythrina abyssinica Erythrina alkaloids: erythraline, erysodine, erysotrine, 8Lam. ex DC. oxoerythraline, and 11-methoxyerysodine [133]

Elabunin exhibited moderate cytotoxic activity with a median effective dose $\left(\mathrm{ED}_{50}\right)$ of $100 \mu \mathrm{g} / \mathrm{mL}$ against L1210 leukemic cells [132]

Cytotoxicity with $\mathrm{LC}_{50}$ value $>240 \mu \mathrm{g} / \mathrm{ml}$ [134]. In vitro cytotoxicity of the crude alkaloidal fraction reported against HeLa, Hep-G2, HEP-2, HCT-116, MCF-7, and HFB4 cell lines with $\mathrm{IC}_{50}$ values of $13.8,10.1,8.16,13.9$, 11.4 , and $12.2 \mu \mathrm{g} / \mathrm{mL}$ [133]

Cytotoxicity of ethanolic roots and stem extracts reported in brine shrimp lethality test [138] Cytotoxicity of crude chloroform extract of the roots, diospyrin, and 7-methyljuglone reported against green

Mamegakinone, diospyrin (22) and 7-methyljuglone from root bark, lupeol, $\beta$-sitosterol, 20(29)-lupene-3isoferulate, Isodiospyrin, 5-hydroxy-4-methoxy-2-

Euclea natalensis A.DC. nathaldehyde, 80-hydroxydiospyrin, neodiospyrin, methylnaphthazarin, euclanone, octahydroeuclein, shinanolone, diospyrin, and natalenone [135-137]

Lapachol, 3-(2'- hydroxyethyl)-5-(2" -hydroxypropyl) Kigelia africana Lam. dihydrofuran-2-(3H)one, specioside, verminoside, and Benth. minecoside, kigelin, $\beta$-sitosterol, 1,3-dimethylkigelin, and ferulic acid

monkey kidney cells (VERO) and a mouse macrophage cell line, J774A.1. Crude extract and diospyrin had $\mathrm{IC}_{50}$ values of 64.87 and $17.78 \mu \mathrm{g} / \mathrm{mL}$ while 7 -methyljuglone effected a $90 \%$ reduction of growth of Mycobacterium tuberculosis Erdman within J774.1 macrophage at $0.57 \mu \mathrm{g} / \mathrm{mL}$ [139] Cytotoxicity of 7-methyljuglone from the root and a series of its derivatives on MCF-7, HeLa, SNO, and DU 145 human cancer cell lines had $\mathrm{IC}_{50}$ values ranging from 5.3 to $10.1 \mu \mathrm{M}$ [135]

Seed oil suppressed human colon adenocarcinoma (Caco-2) and human embryonic kidney (HEK-293) cell growth in a dose-dependent manner [140]

An $80 \%$ methanol extract of the roots exhibited cytotoxicity to brine shrimps with $\mathrm{LC}_{50}$ of $7.2 \mu \mathrm{g} / \mathrm{ml}$ [138] Fruit extracts increased the sub-G1 phase (apoptosis) population in HCT116 human colon cancer cells [141]

Anticancer activity against Ehrlich ascites carcinoma cells with an $\mathrm{IC}_{50}$ value of $27.0 \mu \mathrm{g} / \mathrm{mL}$ [143]. Cytotoxicity against $\mathrm{KB}$ (mouth epidermoid carcinoma) and the human diploid embryonic lung cells (MRC5) though most $\mathrm{IC}_{50}$ values were $>50 \mu \mathrm{g} / \mathrm{mL}$ [144] 
TABLE 2: Continued.

Plant Active phytochemicals

Quercetin, kaempferol, $\beta$-D-glucopyranoside Moringa oleifera Lam tetradecanoate, $\beta$-sitosterol, $\beta$-sitosterol glucoside [145], isothiocyanate, hexadecanoic acid, and eugenol [146]
Molecular targets and/or effects on cancer cells

Cytotoxic against colon cancer (Colo-320 DM), breast cancer (MCF-7), ovary cancer (PA-1), and oral cancer (KB-403) cell lines with $\mathrm{IC}_{90}$ value of $3.98,17.60,12.86$, and $8.40 \mu \mathrm{g} / \mathrm{mL}$, respectively [145]. Methanol extracts were cytotoxic to human B-lymphocyte plasmacytoma

(U266B1) cell line with $\mathrm{IC}_{50}$ of $0.32 \mu \mathrm{g} / \mathrm{ml}$ [147].

Aqueous leaf extract caused a dose-dependent decrease in HeLa cell viability with $\mathrm{IC}_{50}$ of $70 \mu \mathrm{g} / \mathrm{mL}$ [148]. Leaf extracts displayed significant antiproliferative activity

$(p<0.05)$ against human liver (hepatocellular carcinoma, Hep-G2) and muscular

(rhabdomyosarcoma, RD) cell lines [149]. The $\mathrm{IC}_{50}$ of leaf extracts cytotoxicity on cisplatin-resistant ovarian cancer (A2780CP20) and prostate cancer (PC3) cell lines in a study was 0.27 and $0.17 \mathrm{mg} / \mathrm{mL}$, respectively [150]

Apoptosis assay performed using leaf and bark extracts

on breast and colorectal cancer lines showed a remarkable increase in the number of apoptotic cells with a sevenfold increase in breast (MD-MB-231) cell line to an increase of several folds in colorectal cancer (HCT-8) cell line [146]

Leaf extracts inhibited the growth of hepatocarcinoma (HepG2), colorectal adenocarcinoma (Caco-2), and

breast adenocarcinoma (MCF-7) cell lines with dichloromethane leaf extract having $\mathrm{IC}_{50}$ between 112 and $133 \mu \mathrm{g} / \mathrm{ml}$ [151]. Leaf extracts caused the death of $72-82 \%$ of acute myeloid leukemia cells and $77-86 \%$ of acute lymphoblastic leukemia cells after 24 hours of incubation with $20 \mu \mathrm{g} / \mathrm{ml}$ of the extract. At the same time, $69-81 \%$ of HepG 2 cells died after treatment with ethanol extract [152]. Leaf extracts also showed in vitro anticancer activity on human hepatocellular carcinoma (HepG2) cells. At a maximum dose of $200 \mathrm{mg} / \mathrm{kg}$, the survival of HepG2 and non-small-cell lung cancer (A549) cells was reported to decrease by $60 \%$ and $50 \%$, respectively [153]

Leaf extract had anticancer activity against human epidermoid cancer (Hep2) cell line with $\mathrm{IC}_{50}$ of $12.5 \mu \mathrm{g} /$ $\mathrm{mL}$ in the most active fraction [154]. Cytotoxicity of water-soluble leaf extract was reported against human alveolar epithelial cells derived from the lung cancer

(A549) cell line with $\mathrm{IC}_{50}$ of $166.7 \mu \mathrm{g} / \mathrm{mL}$ [155]

Cell viability of leaf extract-treated A549, HepG2,

$\mathrm{CaCo} 2$, Hek293, and Jurkat cells was reported to be reduced with $\mathrm{IC}_{50}$ from 0.05 to $0.4 \%$ [156]

Human pancreatic cancer cells (Panc-1, p34, and COLO-357) were inhibited by leaf extracts with $\mathrm{IC}_{50}$ of $1.1,1.5$, and $1.8 \mathrm{mg} / \mathrm{mL}$ [157]

Seed extracts had cytotoxic potential against A549, Hep-2, HT-29, and IMR-32 cancer cell lines [158].

$\beta$-sitosterol-3-oglucopyranoside, 4 - $(\alpha$-Lrhamnosyloxy) benzyl isothiocyanate, and niazimicin prevented the induction of Epstein-Barr virus genome

in Raji cells. Niazimicin delayed the formation of tumors and reduced the number of tumors in vivo [159] Fruits, peels, seed, cladode, stem, and root extracts of different species have cytotoxicity against mammary (MCF-7), prostate (PC3), colon (Caco2, SW-480, HT29), HeLa cervical carcinoma, myeloid leukemia (K562), and hepatic (HepG2) cell lines [161-164] 
TABLE 2: Continued.

\begin{tabular}{|c|c|c|}
\hline Plant & Active phytochemicals & Molecular targets and/or effects on cancer cells \\
\hline $\begin{array}{l}\text { Oxalis corniculata } \\
\text { Linn. }\end{array}$ & $\begin{array}{l}\text { Palmitic, } 8 \text { oleic, linoleic, linolenic, stearic, tartaric, and } \\
\text { citric acids, flavones (acacetin and } 7,4^{\prime} \text {-diOMe apigenin), } \\
\text { glycoflavones }\left(4^{\prime} \text {-OMe vitexin, } 4^{\prime} \text {-OMeiso-vitexin and }\right. \\
3^{\prime}, 4^{\prime} \text {-diOMe orientin), flavonols }\left(3^{\prime}, 4^{\prime} \text {-diOMe quercetin), }\right. \\
\text { and phenolic acids such as } p \text {-hydroxybenzoic, vanillic, and }\end{array}$ & $\begin{array}{l}\text { The ethanolic extract inhibited tumor growth of Ehrlich } \\
\text { ascites carcinoma (EAC) induced in Swiss albino mice } \\
\text { [166] }\end{array}$ \\
\hline
\end{tabular}

Antiprostate cancer activity targets fast dividing cells by impairing mitosis or by causing target cells to undergo apoptosis $[169,170]$. There was growth inhibition of a human prostate cancer cell line (PC-3) and epithelial cells derived from a lymph-node carcinoma of the

prostate (LNCaP) by $50 \%$ at $2.5 \mu \mathrm{L} / \mathrm{mL}$ and also

Prunus africana

(Hook.f.) Kalkman
Ursolic acid, oleanolic acid, $\beta$-amyrin, atraric acid, $N$ butylbenzene-sulfonamide, $\beta$-sitosterol, $\beta$-sitosterol-3-Oglucoside, ferulic acid, and lauric acid [167-169]

induced significant apoptosis in both cell lines (PC-3 and $\mathrm{LNCaP}$ ) at $2.5 \mu \mathrm{L} / \mathrm{mL}$ compared to untreated cells. The ethanolic extract had an antimitogenic effect on prostate cancer cells by inhibiting the mitogenic action of epidermal growth factor which resulted in a decreased number of cells entering the S-phase of the cell cycle [171]

Extracts showed moderate cytotoxicity with $\mathrm{IC}_{50}$ values below $50 \mu \mathrm{M}$ against the drug-sensitive CCRF-CEM and multidrug-resistant CEM/ADR5000 leukemia cell lines [172]

Skimmianine, furoquinoline alkaloid skimmianine, the benzophenanthridine alkaloids chelerythrine and nitidine, the aporphine alkaloids tembetarine,

Zanthoxylum chalybeum Engl. magnoflorine, $\mathrm{N}$-methylcorydine, $\mathrm{N}$-methylisocorydine (menisperine), and berberine and the phenylethylamine candicine, alkamide, fagaramide, dihydrochelerythrine, lupeol, and sesamin [172]
Stem bark extracts exhibited potential cytotoxicity effect with $\mathrm{LC}_{50}$ value of $5.74 \mu \mathrm{g} / \mathrm{mL}$ in brine shrimp assay [173]

Cytotoxicity reported against human cancer cell line HL-60 cells with $\mathrm{IC}_{50}$ of $137.31 \mu \mathrm{g} / \mathrm{mL}$ and selectivity index of 3.81 [174]. Cytotoxicity against human gingival fibroblasts cells with $\mathrm{IC}_{50}$ of $26 \pm 3 \mu \mathrm{g} / \mathrm{mL}$ [175] Cytotoxicity of root bark extracts reported with $\mathrm{IC}_{50}$ of $38.5,68.9$ and $<500 \mu \mathrm{g} / \mathrm{mL}$ in brine shrimp toxicity assay $[97,134,176]$

$\mathrm{IC}_{50}$ : -median inhibitory concentration/half maximal inhibitory concentration, $\mathrm{LC}_{50}$ : median lethal concentration, and $\mathrm{IC}_{90}$ : concentration inhibiting $90 \%$ of cellular growth.

intake of fruits, vegetables, and teas tends to lower the risk of human cancers [244].

Further, some of the botanical species have been reported as recipes of anticancer preparations in other countries. For example, $P$. africana stem bark is used in combination with Harungana madagascariensis Lam. ex Poir, Zanthoxylum gilletii (De Wild.) P.G. Waterman (stem bark), Spathodea campanulata P. Beauv, and Vernonia lasiopus O. Hoffman (stem bark), and P. africana (stem bark and roots), Aloe volkensii leaves, Spathodea campanulata P. Beauv (leaves and stem bark), and Harungana madagascariensis Lam. ex Poir (stem bark) boiled with Trichilia emetica Vahl. are used for the treatment of skin, breast, and colorectal cancers in Kenya [170]. Similarly, Markhamia lutea (Benth.) K. Schum stem bark alone or in combination with Albizia gummifera stem bark and Conyza sumatrensis (Retz.) E.H Walker leaves is used in the management of squamous cell carcinoma of the gums, colorectal, throat, and breast cancers in Kenya [170]. In Tanzania, Kigelia africana (Lam) Benth. stem bark mixed with approximately equal weights of root barks of Maclura africana (Bureau) corner, Harrisonia abyssinica Oliv., and Warburgia stuhlmannii
Engl. is drunk for the treatment of breast, liver, and colon cancers [97]. Euclea natalensis A. DC. root bark boiled with the root barks of Harrisonia abyssinica is drunk as a treatment for leukemia in Tanzania [97].

Some of the plants have been reported to have cytotoxic and antitumor properties (Table 2) and many possess other ethnomedical applications (Table 3) both in Uganda and internationally. Interestingly, the isolation, characterization, and purification of the anticancer and cytotoxic phytoconstituents have been successfully done in some species (Figure 1). Striking examples are Prunus africana (Hook.f.) Kalkman which have been patented in France for the management of prostate cancer [245] and Catharanthus roseus (L.) G. Don from which the commercial anticancer drugs vincristine and vinblastine have been developed [246].

Phytochemicals from plants are reported to be effective against cancer cells because they have many molecular targets [247]. For example, $\beta$-sitosterol present in $P$. africana has been shown to exhibit anti-inflammatory, antineoplastic, and immunomodulating activities [248]. It is worth mentioning that antioxidant activities and antitumor or anticancer properties of plant extracts are always reported 
<smiles>O=c1c(OC2OC(CO)C([O-])C(O)C2O)c(-c2ccc(O)c(O)c2)oc2cc(O)cc(O)c12</smiles><smiles></smiles><smiles></smiles>

2<smiles>C=CCSCC=C</smiles><smiles>C=CCSSCC=C</smiles>

6<smiles>C=CCS[IH]/C=C\CS(=O)CC=C</smiles><smiles>C=CCSCC(N)C(=O)O</smiles>

10<smiles>CCCCCCCCCCCCC(O)C1CCC(CC(O)CCCC(O)C(O)CCCCCC(O)CC2=CC(C)OC2=O)C1</smiles><smiles>C=CCSSC=CCS(=O)CC=C</smiles><smiles>C=CCS(=O)CC(N)C(=O)O</smiles>

11<smiles></smiles>

12

FIgURE 1: Continued. 


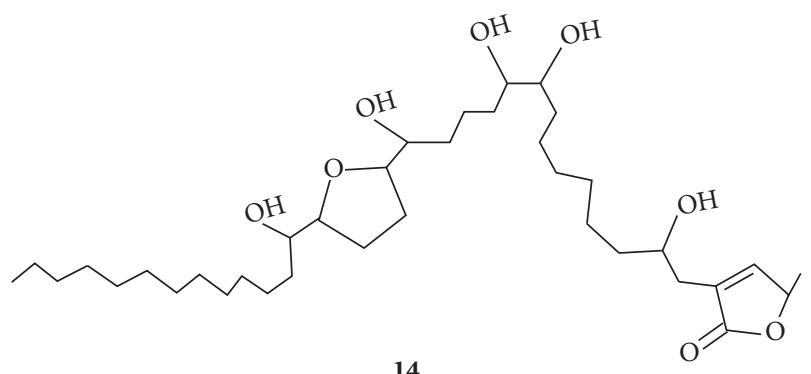<smiles>CC1CCC2C(C)C(=O)OC3OC4(C)CC1C32OO4</smiles><smiles>CC1OC(OCC2OC(Oc3c(-c4ccc(O)c(O)c4)oc4cc(O)cc(O)c4c3=O)C(O)C(O)C2O)C(O)C(O)C1O</smiles><smiles>O=c1c(O)c(-c2ccc(O)cc2)oc2cc(O)cc(O)c12</smiles>

16<smiles>CCCCCc1cc(O)c2c(c1)OC(C)(C)C1CCC(C)=CC21</smiles>

18<smiles>C=C(CCC=C(C)C)[C@]1([C@@H](O)O[C@H]2CC3(C)C4CCC5C(C)(C)C(=O)CCC5(C)C4CCC3C2(C)C)C(=C)CCC1=O</smiles>

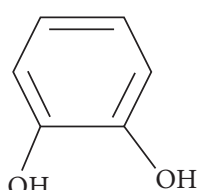

19<smiles>COc1cc(CNC(=O)CCCC/C=C/C(C)C)ccc1O</smiles>

20<smiles>Cc1cc(O)c2c(c1)C(=O)C(c1c(C)cc3c(c1O)C(=O)C=CC3=O)=CC2=O</smiles>

FIGURE 1: Some of the anticancer molecules reported in some anticancer plants used in rural Uganda. The numbers 1-22 correspond to the molecules mentioned in Table 2.

concomitantly in several plants [166], and some studies demonstrated that there is a positive linear relationship between antioxidant activity and anticancer effect of plant extracts [249]. Plant phytochemicals such as artemisinin from the Artemisia genus are reported to have an endoperoxide moiety which is strategic for their bioactivity. The cleavage of this is reported to produce reactive oxygen species, inducing oxidative stress. Furthermore, in the presence of ferrous iron or reduced heme, artemisinin can convert itself into cytotoxic carbon-centred radical, a highly potent alkylating agent, to induce direct oxidative damage to cancer cells $[250,251]$. Thus, they are reported to induce apoptosis and ferroptosis, reduce cell proliferation through cell cycle arrest, and inhibit angiogenesis and tissue invasion of the tumor as well as cancer metastasis [184, 250, 251].

3.3. Growth Habit, Parts Used, Preparation, and Mode of Administration. Most anticancer plant species reported in Uganda occur in the wild (52\%) though some are cultivated (48\%). The growth habit of the plants is as trees $(55 \%)$ or herbs $(45 \%)$. Anticancer extracts are usually prepared from leaves $(29 \%)$, bark $(24 \%)$, roots $(21 \%)$, fruits $(13 \%)$, seeds $(5 \%)$, bulb $(5 \%)$, or rhizomes $(3 \%)$. The regular use of roots 
TABLE 3: Ethnomedicinal uses and other biological activities of the anticancer plant species reported in Uganda as per global studies.

\begin{tabular}{lcc}
\hline Plant & Ethnomedicinal uses & Biological activities \\
\hline $\begin{array}{l}\text { Abelmoschus } \\
\text { esculentus (L.) }\end{array}$ & $\begin{array}{c}\text { Treatment of syphilis, immunity boosting and } \\
\text { treatment of anaemia, cuts, wounds, boils, catarrhal } \\
\text { infections, ardor urinae, dysuria, and gonorrhoea }\end{array}$ & $\begin{array}{c}\text { Immunomodulating, antioxidant, antidiabetic, and } \\
\text { antihyperlipidemic activities [178] }\end{array}$
\end{tabular}

Moench

Albizia coriaria

(Welw. Ex Oliver)

Allium sativum L.

Annona muricata L.

Artemisia annua L.

Beta vulgaris L.

Blighia unijugata

Baker

Opuntia species

Cannabis sativa $\mathrm{L}$.

Canarium schweinfurthii Engl.

Carica papaya L.

Capsicum frutescens $\mathrm{L}$.

$$
\text { [177] }
$$

Treatment of heart diseases, meat allergy, nausea, headaches, mental illness, diarrhea, cough, tuberculosis, anaemia, syphilis, postpartum haemorrhage, snakebites, sore throats, herpes zoster, menorrhagia, stimulating milk production in lactating mothers, threatened abortion, skin diseases, jaundice, cough, steam fumigation treatments for sore eyes, and as a general tonic $[33,142,179]$

Arteriosclerosis, management of diabetes mellitus, asthma, deafness, leprosy, bronchial congestion, fevers, worms, and liver gall bladder trouble [180] Leaves are used to treat cystitis, diabetes, headaches, colds, flu, asthma, and insomnia [182]

Treatment of cough, indigestion, malaria, fever caused by tuberculosis, and jaundice [33]

Management of hypertension, purifying blood and liver, and reducing inflammation [32]

Treating fibroids [43], vomiting, malaria, and skin diseases [185]

Treatment of skin wounds, stomach swelling, digestive problems, type 2 diabetes, colitis, high cholesterol, urinary tract infections, weight loss aid to treat obesity and overweight, and as a remedy for alcohol hangovers [40, 41, 187]

Treatment of cough, tuberculosis, cancer pain, asthma and diarrhea [33], appetite stimulant in debilitating diseases, attenuation of wasting [189], antiemetics, treatment of multiple sclerosis, spinal cord injuries, Tourette's syndrome, epilepsy, and glaucoma [190] Management of anaemia [39], dysentery, coughs, chest pains, tuberculosis, stomach complaints, food poisoning, purgative and emetic, roundworm infections and other intestinal parasites. Used as an emollient, stimulant, diuretic and in treatment of skin infections, eczema, leprosy, ulcers, diabetes mellitus, colic, stomach pains, pains after childbirth, gale, inappetence, fever, constipation, malaria, sexually transmitted infection, and rheumatism [33, 192, 193] Treatment of cough, diarrhea, snake bite, sterility, pain killer, antidotes, promotes labour, cracks on soles of feet, low immunity, loss of memory, measles, erectile dysfunction [42, 43], and fevers [196], leaves used as an antipyretic, for malaria, splenomegaly, and HIV treatment [33, 185, 197, 198]. Fruit used to manage anaemia, worms, asthma, and tonsillitis [199]. Root extracts with that of Carissa edulis and Euclea divinorum used for treatment of venereal diseases [200]

Management of hernia, pancreas disorders, erectile dysfunction (roots) [43]. Used with Clematis hirsuta Perr. \& Guill. for treating influenza and mental problems [202], headache, and indigestion [199]. As a salve to relieve muscle, joint, and toothache pain, to treat cough, asthma, and sore throat, as a stimulant, and to treat stomachache, seasickness, and flatulence antihyperlipidemic activities [178]

Antibacterial activity [58]

Antidiabetic, hepatoprotective, antimicrobial, and antihyperlipidemic activities [181]

Antiviral, antinociceptive, anti-inflammatory, and antihyperglycemic activities [183]

Antimalarial, antimicrobial, and anti-inflammatory activities [184]

Antioxidant and antibacterial activities [94]

Antiplasmodial, antimalarial, and antioxidant activities [186]

Antidiabetic, antimicrobial, antioxidant, and antiinflammatory activities [188]

Anti-inflammatory and antinociceptive activities [191]

Antioxidant, analgesic, antibacterial, anti-inflammatory, and antidiabetic activities $[194,195]$

Antibacterial, antimalarial, antifungal, and immunomodulatory activities $[106,107,201]$

Insulinotropic activities [204] 
TABLE 3: Continued.

\begin{tabular}{|c|c|c|}
\hline Plant & Ethnomedicinal uses & Biological activities \\
\hline $\begin{array}{l}\text { Catharanthus roseus } \\
\text { (L.) G. Don. }\end{array}$ & $\begin{array}{l}\text { Treatment of diabetes, malaria, dengue fever, } \\
\text { dysentery, insect bites, skin infection, diarrhea, } \\
\text { leukemia, eye irritation, dyspepsia, dysentery, } \\
\text { toothache, sore throat, and lung congestion [205-207] }\end{array}$ & $\begin{array}{c}\text { Anti-inflammatory, antibacterial, antifungal, antidiabet } \\
\text { antihypercholesterolemic, antiandrogenic, and } \\
\text { antiangiogenic activities [208] }\end{array}$ \\
\hline $\begin{array}{l}\text { Citrus reticulata } \\
\text { Blanco, } 1837\end{array}$ & $\begin{array}{c}\text { Treatment of skin diseases, malaria, and inducing } \\
\text { weight loss [42] }\end{array}$ & Antimalarial and antioxidant activities $[121,122]$ \\
\hline $\begin{array}{l}\text { Cymbopogon citratus } \\
\text { (DC) Stapf }\end{array}$ & $\begin{array}{c}\text { Treatment of cough, fever, indigestion, pain in } \\
\text { fallopian tubes }[42,43] \text {, malaria, and dental caries } \\
\text { [185] }\end{array}$ & Antimalarial activity [125] \\
\hline Daucus carota L. & $\begin{array}{l}\text { Treating skin diseases and wounds [34], fatigue [33], } \\
\text { cough, diarrhea, dysentery, malaria, as an antiseptic, } \\
\text { abortifacient, aphrodisiac, carminative, stimulant, } \\
\text { stomachic, and tonic [209] }\end{array}$ & Antioxidant and hepatoprotective activities [127] \\
\hline $\begin{array}{l}\text { Elaeodendron } \\
\text { buchananii (Loes) } \\
\text { Loes. }\end{array}$ & $\begin{array}{l}\text { Treatment of wounds, syphilis, cough, and dysentery } \\
\text { [210], blocked fallopian tube [43], candida [211], and } \\
\text { urinary tract infections [212] }\end{array}$ & Antimicrobial, antioxidant and antifungal activities \\
\hline $\begin{array}{l}\text { Erythrina abyssinica } \\
\text { Lam. ex DC. }\end{array}$ & $\begin{array}{l}\text { Treatment of viral infections [133], yellow fever, } \\
\text { convulsions, anaemia, infertility in women, hiccup, } \\
\text { vomiting, and urinary tract infections [212] }\end{array}$ & Antifungal activity [133] \\
\hline $\begin{array}{l}\text { Euclea natalensis A. } \\
\text { DC. }\end{array}$ & $\begin{array}{c}\text { Remedy for chest ailments, toothache, bronchitis, } \\
\text { pleurisy, asthma, headache, and urinary tract } \\
\text { infections }[213,214]\end{array}$ & $\begin{array}{l}\text { Antiplasmodial, antioxidant, antidiabetic, and } \\
\text { antibacterial activities [215] }\end{array}$ \\
\hline Ficus dawei Hutch. & Treating wounds [43] & NR \\
\hline $\begin{array}{l}\text { Ficus natalensis } \\
\text { Hochst. }\end{array}$ & $\begin{array}{l}\text { Treatment of HIV [198], diarrhea, vomiting, } \\
\text { snakebites [33, 44], and heart diseases [179] }\end{array}$ & NR \\
\hline $\begin{array}{l}\text { Lovoa trichilioides } \\
\text { Harms }\end{array}$ & $\begin{array}{l}\text { Management of skin lesions, infections, and diarrhea } \\
\text { [33] }\end{array}$ & NR \\
\hline
\end{tabular}

Kigelia africana Lam. Treatment of wounds [35], skin diseases, eczema, Benth.

psoriasis and leprosy [36], rheumatism, snakebites, and syphilis [216]

Management of anaemia, liver disease, inappetence, stomachache, headache, skin rash, cataracts, throat

Markhamia lutea

(Benth.) K. Schum.

diseases, conjunctivitis, backache, and snakebites $[33,210,218]$

Cleansing blood and liver, strengthening the heart, increasing fat metabolism to promote weight loss, deworming, improving wound healing, reducing wrinkles, improving digestion, eliminating constipation, and body detoxification $[45,220]$

Treatment of athletes foot, wounds, hypertension,

Oxalis corniculata L. diabetes and hormonal imbalance [43], stomachache and migraine [44], excessive menstruation, cough, and antidote to poisoning [199]

Used for managing fainting [43], malaria, HIV, cough,

Prunus africana

(Hook.f.) Kalkman

Vitex fischeri Gürke

Zanthoxylum

chalybeum Engl. chest pain, epilepsy, heart diseases, diarrhea [33, 198], urinary tract infections, pregnancy [44], fever, and inappetence [102]

Treatment of herpes zoster, skin infections, rashes, tuberculosis [33]

Treatment of stomachache, cough, fever, skin rush, diabetes [33, 42, 43], HIV [198], malaria, diarrhea, sickle cell, tuberculosis, pneumonia, colds, ulcers, sore throat, measles, bilharzia, amoebiasis, female sterility, uterine fibroids, and headache [226-230]
Antibacterial, antifungal, anti-inflammatory, analgesic, antidiabetic, and antioxidant activities [217]

Antioxidant, antileishmanial, and antitrypanosomal activities [143, 144, 219]

Potent antioxidant, cardioprotective, antibacterial, hepatoprotective, antihypertensive, antiulcer, and antiinflammatory activities [221, 222]

Antifungal and antioxidative activities [223]

Anti-inflammatory, antioxidant, and antimalarial activities $[215,224]$

Anticandidal activity [211, 225]

Anticandidal, antibacterial, and antidiabetic activities $[173,231-233]$

NR: none retrieved in the open literature.

and leaves in traditional medicine is a characteristic feature of materia medica in Uganda [26]. As reported elsewhere $[238,240]$, embryonal plant parts such as fruits, seeds, buds, bulbs, and flowers which are reported to accumulate bioactive compounds are less frequently used in anticancer therapy in Uganda.

Usually, anticancer preparations are presented as decoctions and teas (53\%) and spices eaten in food $(23 \%)$ or 
pounded to produce ointments that are applied topically $(10 \%)$. The plants are collected from the wild, cultivated fields, or home gardens when needed. Traditional medicine practitioners either collect herbal plants personally or hire collectors. All traditional medical practitioners cultivate some medicinal plants especially fast growing ones around their homes and shrines in order to have them within easy access when needed [26]. The preparations are majorly administered orally, except in cases of skin cancers where they are applied topically as ointments.

3.4. Other Ethnomedicinal Uses and Toxicity of the Reported Anticancer Plants. Almost all the plants recapitulated in this review are employed for the treatment of various ailments other than cancer. Albizia coriaria (Welw. ex) Oliver used in the management of venereal diseases (syphilis, HIV, and gonorrhoea), postpartum haemorrhage, sore throats, menorrhagia, threatened abortion, skin diseases, jaundice, cough, and sore eyes [33, 179] is a good representative example. Such plants tend to be used in different communities for treating cancer and can be a good justification for their pharmacological efficacy [26].

On the other hand, some of the anticancer plants cited exhibit marked toxicity. A striking example is Catharanthus roseus (L.) G. Don. The alkaloids in it are neurotoxic, especially vincristine [252]. Vincristine and vinblastine are highly toxic antimitotics, blocking mitosis in metaphase after binding to the microtubules [253]. Evidently, side effects such as myelosuppression, alopecia, abdominal cramps, constipation, nausea, paralytic ileus, ulcerations of the mouth, hepatocellular damage, kidney impairment, pulmonary fibrosis, urinary retention, amenorrhoea, azoospermia, orthostatic hypotension, and hypertension [254-256] have been reported for the commercial drugs vincristine and vinblastine derived from this plant. In essence, the administration of these drugs must be carefully controlled to reduce the side effects [257]. This observation explains, in part, why some anticancer preparations in Uganda are applied topically or ingested in small amounts. Fortuitously, topical application is a better approach for reducing the local action of cancer cells at externally affected parts.

3.5. Clinical Studies. At present, clinical trials utilizing standardized extracts of anticancer plants reported in Uganda or their bioactive compounds have not been done with the exception of Prunus africana (Hook.f.) Kalkman and Catharanthus roseus (L.) G. Don. which have been investigated in other countries [245, 246]. Prostafx, Tadenan, and Pygenil are some of the herbal preparations of Prunus africana (Hook.f.) Kalkman on the market. Due to the paucity of data generated from preclinical tests (pharmacokinetic and toxicological studies) and the regulatory requirements for clinical studies, the safety and efficacy of traditional anticancer plant preparations used in Uganda remain a secret yet to be unveiled. Although there are many research institutes such as Uganda Virus Research Institute, Natural Chemotherapeutic Research Institute, Uganda
Industrial Research Institute, and National Agricultural Research Institute, none is designed to have an in-depth focus on drug discovery and development to the level of commercialization. Thus, the government of Uganda should establish an institute that handles drug discovery and development to enhance the utilization of medicinal plants in Uganda.

\section{Conclusions and Recommendations}

The inventory of plants utilized by Ugandan communities presents considerable potential for the treatment of cancer. Cyperus alatus (Nees) F. Muell, Ficus dawei Hutch, Ficus natalensis Hochst, and Lovoa trichilioides Harms are some of the plants with claimed anticancer potential that have been hardly studied and therefore warrant further investigations. More ethnobotanical surveys should be done in the unsurveyed districts to identify other potential anticancer plants. Albizia coriaria Welw. ex Oliver which doubles as an antivenin plant will be investigated for its anticancer potential in a penultimate study.

\section{Disclosure}

Timothy Omara and Sarah Kagoya are co-first authors.

\section{Conflicts of Interest}

The authors declare that there are no conflicts of interest regarding the publication of this paper.

\section{Authors' Contributions}

Timothy Omara and Sarah Kagoya contributed equally.

\section{Acknowledgments}

TO, DMN, PN, LNK, AJ, AM, BJK, IM, CKN, and MKC are grateful to the World Bank and the Inter-University Council of East Africa for the scholarship awarded to them through the Africa Center of Excellence II in Phytochemicals, Textiles, and Renewable Energy (ACE II PTRE) hosted at Moi University that prompted this concerted ethnomedical communication. The authors commend preceding authors for their useful quest for knowledge on medicinal plants in Uganda, the reports of which this study was based.

\section{References}

[1] WHO, Cancer, WHO, Geneva, Switzerland, 2000, http:// www.who.int/mediacentre/factsheets/fs297/en/.

[2] A. Gondos, H. Brenner, H. Wabinga, and D. M. Parkin, "Cancer survival in Kampala, Uganda," British Journal of Cancer, vol. 92, no. 9, pp. 1808-1812, 2005.

[3] Facts About Cancer in Uganda, 2019, https://www.health.go. ug/download/file/fid/541.

[4] J. N. P. Davies and B. A. Wilson, "Cancer in Kampala, 19521953,” East African Medical Journal, vol. 31, pp. 395-416, 1954.

[5] H. R. Wabinga, D. M. Parkin, F. Wabwire-Mangen et al., "Trends in cancer incidence in Kyadondo county, Uganda, 
1960-1997," British Journal of Cancer, vol. 82, pp. 1585-1592, 2000.

[6] D. M. Parkin, H. Wabinga, S. Nambooze, and F. WabwireMangen, "AIDS-related cancers in Africa: maturation of the epidemic in Uganda," AIDS, vol. 13, no. 18, pp. 2563-2570, 1999.

[7] MOH, Strategic Plan for Cervical Cancer Prevention and Control in Uganda, 2010-2014, Ministry of Health, Kampala, Uganda, 2010.

[8] L. Bruni, L. Barrionuevo-Rosas, G. Albero et al., "Human papillomavirus and related diseases in Uganda," Summary report, ICO Information Centre on HPV and Cancer, Barcelona, Spain, 2016.

[9] R. Ndejjo, T. Mukama, A. Musabyimana, and D. Musoke, "Uptake of cervical cancer screening and associated factors among women in rural Uganda: a cross sectional study," PLoS One, vol. 11, Article ID e0149696, 2016.

[10] B. Kavishe, S. Biraro, K. Baisley et al., "High prevalence of hypertension and risk factors for non-communicable diseases (NCDs): a population based cross-sectional survey of NCDS and HIV infection in Northwestern Tanzania and Southern Uganda," BMC Medicine, vol. 13, no. 1, pp. 1-21, 2015.

[11] E. Black, F. Hyslop, and R. Richmond, "Barriers and facilitators to uptake of cervical cancer screening among women in Uganda: a systematic review," BMC Women's Health, vol. 19, p. 108, 2019.

[12] C. Nakisige, M. Schwartz, and A. O. Ndira, "Cervical cancer screening and treatment in Uganda," Gynecologic Oncology Reports, vol. 20, pp. 37-40, 2017.

[13] A. D. Mwaka, E. S. Okello, H. Wabinga, and F. M. Walter, "Symptomatic presentation with cervical cancer in Uganda: a qualitative study assessing the pathways to diagnosis in a low-income country," BMC Women's Health, vol. 15, no. 1, p. 51, 2015.

[14] H. R. Wabinga, S. Nambooze, P. M. Amulen, C. Okello, L. Mbus, and D. M. Parkin, "Trends in the incidence of cancer in Kampala, Uganda 1991-2010," International Journal of Cancer, vol. 135, no. 2, pp. 432-439, 2014.

[15] GLOBOCAN 2018, "Uganda-global cancer observatory," WHO, International Agency for Research on Cancer, Geneva, Switzerland, 2019, http://gco.iarc.fr/today/data/ factsheets/populations/800-uganda-fact-sheets.pdf.

[16] The New York Times, Uganda Fights Stigma and Poverty to Take on Breast Cancer, The New York Times, New York, NY, USA, 2013, https://www.nytimes.com/2013/10/16/health/ uganda-fights-stigma-and-poverty-to-take-on-breast-cancer. html.

[17] T. Omara, S. Karungi, R. Kalukusu, B. V. Nakabuye, S. Kagoya, and B. Musau, "Mercuric pollution of surface water, superficial sediments, Nile tilapia (Oreochromis nilotica Linnaeus 1758 [Cichlidae]) and yams (Dioscorea alata) in auriferous areas of Namukombe stream, Syanyonja, Busia, Uganda," PeerJ, vol. 7, p. e7919, 2019.

[18] D. Kitya, G. Bbosa, and E. Mulogo, "Aflatoxin levels in common foods of South Western Uganda: a risk factor to hepatocellular carcinoma," European Journal of Cancer Care, vol. 19, no. 4, pp. 516-521, 2009.

[19] T. Omara, W. Nassazi, T. Omute et al., "Aflatoxins in Uganda: an encyclopedic review of the etiology, epidemiology, detection, quantification, exposure assessment, reduction and control," International Journal of Microbiology, vol. 2020, Article ID 4723612, 18 pages, 2020.
[20] C. Nguyen, A. Mehaidli, K. Baskaran et al., "Dandelion root and lemongrass extracts induce apoptosis, enhance chemotherapeutic efficacy, and reduce tumour xenograft growth in vivo in prostate cancer," Evidence-Based Complementary and Alternative Medicine, vol. 2019, Article ID 2951428, 12 pages, 2019.

[21] A. Singh and J. Settleman, "EMT, cancer stem cells and drug resistance: an emerging axis of evil in the war on cancer," Oncogene, vol. 29, no. 34, pp. 4741-4751, 2010.

[22] Y. A. Luqmani, "Mechanisms of drug resistance in cancer chemotherapy," Medical Principles and Practices, vol. 14, no. Suppl. 1, pp. 35-48, 2005.

[23] New Vision, 2018, Uganda Should Invest in Herbal Medicine Research to Fight Cancer, https://www.newvision.co.ug/ new_vision/news/1484720/uganda-invest-herbal-medicineresearch-fight-cancer.

[24] IUCN, "Biodiversity in Sub-Saharan Africa and its Islands: conservation, management, and sustainable use," in Occasional Papers of the IUCN Species Survival Commission No. 6, IUCN. The World Conservation Union, Gland, Switzerland, 1990.

[25] H. H. N. Mayunga, "Towards the discovery of drugs and pesticide agents from east Africa flora," in Proceedings of the 12th NAPRECA Symposium, Kampala, Uganda, June 2007.

[26] T. Omara, S. Kagoya, A. Openy et al., "Antivenin plants used for treatment of snakebites in Uganda: ethnobotanical reports and pharmacological evidences," Tropical Medicine and Health, vol. 48, no. 6, pp. 1-16, 2020.

[27] L. Hoareau and E. J. DaSilva, "Medicinal plants: a reemerging health aid," Electronic Journal of Biotechnology, vol. 2, no. 2, pp. 56-70, 1999.

[28] J. G. Graham, M. L. Quinn, D. S. Fabricant, and N. R. Farnsworth, "Plants used against cancer - an extension of the work of Jonathan Hartwell," Journal of Ethnopharmacology, vol. 73, no. 3, pp. 347-377, 2000.

[29] R. Kaur, K. Kapoor, and H. Kaur, "Plants as a source of anticancer agents," Journal of Natural Products and Plant Resources, vol. 1, no. 1, pp. 119-124, 2011.

[30] E. Solowey, M. Lichtenstein, S. Sallon, H. Paavilainen, E. Solowey, and H. Lorberboum-Galski, "Evaluating medicinal plants for anticancer activity," The Scientific World Journal, vol. 2014, Article ID 721402, 12 pages, 2014.

[31] Daily Monitor, Natural Remedies and Cancer: What's the Truth?, 2019, https://www.monitor.co.ug/SpecialReports/ Natural-remedies-cancer-What-s-truth/688342-5317906pe8w46z/index.html.

[32] Beetroot in Uganda, 2019, https://www.africa-ugandabusiness-travel-guide.com/beetrootinuganda.html.

[33] G. Anywar, E. Kakudidi, R. Byamukama, J. Mukonzo, A. Schubert, and H. Oryem-Origa, "Indigenous traditional knowledge of medicinal plants used by herbalists in treating opportunistic infections among people living with HIV/ AIDS in Uganda," Journal of Ethnopharmacology, vol. 246, Article ID 112205, 2020.

[34] C. Nambejja, P. Tugume, C. Nyakoojo, and M. KamatenesiMugisha, "Medicinal plant species used in the treatment of skin diseases in Katabi sub-county, Wakiso district, Uganda," Ethnobotany Research and Applications, vol. 18, pp. 1-17, 2019.

[35] C. Osinde, M. Kamatenesi-Mugisha, and H. Oryem-Origa, "Medicinal plant species used for treating HIV/AIDS and opportunistic infections in eastern Uganda," Academia Journal of Medicinal Plants, vol. 2, no. 3, pp. 032-048, 2014. 
[36] Leadership, Kigelia Africana (Sausage Tree), 2016, http:// leadershipmagazine.org/? $\mathrm{p}=8768$.

[37] H. Oryem-Origa, A. B. Katende, and E. K. Z. Kakudidi, "Ethnobotanical studies of Mabira forest area, central Uganda," African Academic Science, pp. 169-181, 2001.

[38] H. Oryem-Origa, A. B. Katende, and E. K. Z. Kakudidi, "Some medicinal plants used in Mukono District," Uganda Journal, vol. 49, pp. 56-65, 2003.

[39] E. Kakudidi, C. Kirimuhuzya, G. Anywar, E. Katuura, and J. Kiguli, "Medicinal plants used in the management of noncommunicable diseases in Uganda," in Medicinal Plants-Recent Advances in Research and Development, H.-S. Tsay, Ed., Vol. 22, Springer, Berlin, Germany, 2016.

[40] How to Grow Cactus in Uganda, 2019, https://www.africauganda-business-travel-guide.com/how-to-grow-cactus-inuganda.html.

[41] New Vision, Cactus Can Be Good Food, 2017, https://www. newvision.co.ug/new_vision/news/1459903/cactus-food.

[42] P. Kodi, M. E. Mwangi, C. P. Kiplagat, and T. S. Karuiki, "Ethnobotanical survey of antimalarial medicinal plants used in Butebo county, Eastern Uganda," European Journal of Medicinal Plants, vol. 21, no. 4, pp. 1-22, 2017.

[43] P. Tugume, E. K. Kakudidi, M. Buyinza et al., "Ethnobotanical survey of medicinal plant species used by communities around Mabira central forest reserve, Uganda," Journal of Ethnobiology and Ethnomedicine, vol. 12, no. 1, p. 28, 2016.

[44] J. Kigenyi, "Coping with resource extinction: the case of medicinal plants in Kawete village, Iganga district, Uganda," Culture and Environment in Africa Series, Vol. 9, The Cologne African Studies Centre, Cologne, Germany, 2016.

[45] M. Wamai, Minds Illuminated as Mak Hosts the Day of Moringa Science, Makerere University, Kampala, Uganda, 2019, https://news.mak.ac.ug/2019/07/minds-illuminatedmak-hosts-day-moringa-science.

[46] R. Komakech, Y. Kang, J.-H. Lee, and F. Omujal, “A review of the potential of phytochemicals from Prunus africana (hook f.) kalkman stem bark for chemoprevention and chemotherapy of prostate cancer," Evidence-Based Complementary and Alternative Medicine, vol. 2017, Article ID 3014019, 10 pages, 2017.

[47] The Plant List, 2019, https://www.theplantlist.org/.

[48] International Plant Names Index, 2019, https://www.ipni. org/.

[49] NCBI Taxonomy Browser, 2019, https://www.ncbi.nlm.nih. gov/taxonomy.

[50] Tropicos, 2019, http://www.tropicos.org/.

[51] W. Chaemsawang, W. Prasongchean, K. I. Papadopoulos, G. Ritthidej, S. Sukrong, and P. Wattanaarsakit, "The effect of okra (Abelmoschus esculentus (L.) moench) seed extract on human cancer cell lines delivered in its native form and loaded in polymeric micelles," International Journal of Biomaterials, vol. 2019, Article ID 9404383, 13 pages, 2019.

[52] F. Chen, X. Chen, D. Yang et al., "Isoquercitrin inhibits bladder cancer progression in vivo and in vitro by regulating the PI3K/Akt and PKC signaling pathways," Oncology Reports, vol. 36, no. 1, pp. 165-172, 2016.

[53] Q. Chen, P. Li, P. Li, Y. Xu, Y. Li, and B. Tang, "Isoquercitrin inhibits the progression of pancreatic cancer in vivo and in vitro by regulating opioid receptors and the mitogen-activated protein kinase signalling pathway," Oncology Reports, vol. 33, no. 2, pp. 840-848, 2015.

[54] N. G. Amado, D. Predes, B. F. Fonseca et al., "Isoquercitrin suppresses colon cancer cell growthin vitroby targeting the
Wnt/ $\beta$-catenin signaling pathway," Journal of Biological Chemistry, vol. 289, no. 51, pp. 35456-35467, 2014.

[55] L. G. Monte, T. Santi-Gadelha, L. B. Reis et al., "Lectin of Abelmoschus esculentus (okra) promotes selective antitumor effects in human breast cancer cells," Biotechnology Letters, vol. 36, no. 3, pp. 461-469, 2014.

[56] O. P. Note, A. C. Mitaine-Offer, T. Miyamoto et al., "Cytotoxic acacic acid glycosides from the roots of Albizia coriaria," Journal of Natural Products, vol. 72, no. 10, pp. 1725-1730, 2009.

[57] O. P. Noté, P. Chabert, D. E. Pegnyemb, B. Weniger, M.-A. Lacaille-Dubois, and A. Lobstein, "Structure elucidation of new acacic acid-type saponins from Albizia coriaria," Magnetic Resonance in Chemistry, vol. 48, no. 10, pp. 829-836, 2010.

[58] R. Byamukama, G. Barbara, J. Namukobe, M. Heydenreich, and B. Kiremire, "Bioactive compounds in the stem bark of," International Journal of Biological and Chemical Sciences, vol. 9, no. 2, pp. 1013-1024, 2015.

[59] E. V. Kigondu, G. M. Rukunga, J. M. Kerik et al., "Antiparasitic activity and cytotoxicity of selected medicinal plants from Kenya," Journal of Ethnopharmacology, vol. 123, pp. 505-509, 2009.

[60] M. Yoo, S. Lee, S. Kim et al., "Composition of organosulfur compounds from cool- and warm-type garlic (Allium sativum L.) in Korea," Food Science and Biotechnology, vol. 23, pp. 337-344, 2014.

[61] M. Bagul, S. Kakumanu, and T. A. Wilson, "Crude garlic extract inhibits cell proliferation and induces cell cycle arrest and apoptosis of cancer cells in vitro," Journal of Medicinal Foods, vol. 18, no. 7, pp. 731-737, 2015.

[62] S.-S. Shin, J.-H. Song, B. Hwang et al., "HSPA6 augments garlic extract-induced inhibition of proliferation, migration, and invasion of bladder cancer EJ cells; implication for cell cycle dysregulation, signaling pathway alteration, and transcription factor-associated mmp-9 regulation," PLoS One, vol. 12, no. 2, Article ID e0171860, 2017.

[63] X. Y. Jiang, X. S. Zhu, W. Z. Huang et al., "Garlic-derived organosulfur compound exerts antitumor efficacy via activation of MAPK pathway and modulation of cytokines in SGC-7901 tumor-bearing mice," International Immunopharmacology, vol. 48, pp. 135-145, 2017.

[64] Y.-S. Xu, J.-G. Feng, D. Zhang et al., "S-allylcysteine, a garlic derivative, suppresses proliferation and induces apoptosis in human ovarian cancer cells in vitro," Acta Pharmacologica Sinica, vol. 35, no. 2, pp. 267-274, 2014.

[65] W. Wang, J. W. Cheng, and Y. Z. Zhu, “The JNK signaling pathway is a novel molecular target for S-propargyl-l-cysteine, a naturally-occurring garlic derivatives: link to its anticancer activity in pancreatic cancer in vitro and in vivo," Current Cancer Drug Targets, vol. 15, no. 7, pp. 613-623, 2015.

[66] J. Xiao, F. Y. Xing, Y. X. Liu et al., "Garlic-derived compound S-allylmercaptocysteine inhibits hepatocarcinogenesis through targeting LRP6/Wnt pathway," Acta Pharmaceutica Sinica B, vol. 8, no. 4, pp. 575-586, 2018.

[67] Y. Zhang, H. Y. Li, Z. H. Zhang et al., "Garlic-derived compound S-allylmercaptocysteine inhibits cell growth and induces apoptosis via the JNK and p38 pathways in human colorectal carcinoma cells," Oncology Letters, vol. 8, no. 6, pp. 2591-2596, 2014.

[68] A. H. R. Vasanthi, D. P. Mansingh, N. Dalpati, and V. K. Sali, "Alliin the precursor of allicin in garlic extract mitigates proliferation of gastric adenocarcinoma cells by modulating 
apoptosis," Pharmacognosy Magazine, vol. 14, no. 55, pp. S84-S91, 2018.

[69] Y. Jung, H. Park, H. Y. Zhao et al., "Systemic approaches identify a garlic-derived chemical, Z-ajoene, as a glioblastoma multiforme cancer stem cell-specific targeting agent," Molecular Cells, vol. 37, no. 7, pp. 547-553, 2014.

[70] S. Sun, J. Liu, H. Kadouh, X. Sun, and K. Zhou, "Three new antiproliferative annonaceous acetogenins with mono-tetrahydrofuran ring from graviola fruit (Annona muricata)," Bioorganic Medicine and Chemistry Lettets, vol. 24, no. 12, pp. 2773-2776, 2014.

[71] S.-S. F. Yuan, H.-L. Chang, H.-W. Chen et al., “Annonacin, a mono-tetrahydrofuran acetogenin, arrests cancer cells at the G1 phase and causes cytotoxicity in a Bax-and caspase-3related pathway," Life Science, vol. 72, no. 25, pp. 2853-2861, 2003.

[72] F.-E. Wu, Z.-M. Gu, L. Zeng et al., "Two new cytotoxic monotetrahydrofuran Annonaceous acetogenins, annomuricins A and B, from the leaves of Annona muricata," Journal of Natural Products, vol. 58, no. 6, pp. 830-836, 1995.

[73] V. C. George, D. Kumar, V. Rajkumar, P. Suresh, and R. A. Kumar, "Quantitative assessment of the relative antineoplastic potential of the $n$-butanolic leaf extract of Annona muricata Linn. in normal and immortalized human cell lines," Asian Pacific Journal of Cancer Prevention, vol. 13, no. 2, pp. 699-704, 2012.

[74] L. Valencia, D. L. Muñoz, S. M. Robledo et al., "Actividad tripanocida y citotóxica de extractos de plantas colombianas," Biomédica, vol. 31, no. 4, pp. 552-559, 2011.

[75] M. R. M. Roduan, R. A. Hamid, H. Sulaiman, and N. Mohtarrudin, "Annona muricata leaves extracts prevent DMBA/TPA-induced skin tumorigenesis via modulating antioxidants enzymes system in ICR mice," Biomedicine \& Pharmacotherapy, vol. 94, pp. 481-488, 2017.

[76] Y.-M. Ko, T.-Y. Wu, Y.-C. Wu, F.-R. Chang, J.-Y. Guh, and L.-Y. Chuang, "Annonacin induces cell cycle-dependent growth arrest and apoptosis in estrogen receptor-a-related pathways in MCF-7 cells," Journal of Ethnopharmacology, vol. 137, no. 3, pp. 1283-1290, 2011.

[77] S. Z. Moghadamtousi, E. Rouhollahi, H. Karimian et al., "The chemopotential effect of Annona muricata leaves against azoxymethane-induced colonic aberrant crypt foci in rats and the apoptotic effect of acetogenin annomuricin E in HT29 cells: a bioassay-guided approach," PLoS One, vol. 10, no. 4, Article ID e0122288, 2015.

[78] M. P. Torres, S. Rachagani, V. Purohit et al., "Graviola: a novel promising natural-derived drug that inhibits tumorigenicity and metastasis of pancreatic cancer cells in vitro and in vivo through altering cell metabolism," Cancer Letters, vol. 323, no. 1, pp. 29-40, 2012.

[79] S. U. F. S. Najmuddin, M. F. Romli, M. Hamid, N. B. Alitheen, and N. M. A. N. A. Rahman, "Anti-cancer effect of Annona muricata Linn leaves crude extract on breast cancer cell line," BMC Complementary and Alternative Medicine, vol. 16, no. 1, p. 311, 2016.

[80] V. Oviedo, M. García, C. Díaz et al., "Extracto y fracción alcaloidal de Annona muricata con actividad de tipo ansiolítica en ratones," Revista Colombiana de Ciencias Químico-Farmacéuticas, vol. 38, pp. 105-120, 2009.

[81] A. N. Artanti, O. P. Astirin, and A. Prayitno, "Cytotoxic activity of non polar fraction from Annona muricata L. leaves on hela and raji cell lines," Journal of Pharmaceutical Sciences and Clinical Research, vol. 1, no. 2, pp. 112-118, 2016.
[82] M. N. M. Rosdi, N. N. N. N. M. Daud, R. M. Zulkifli, and H. Ya'akob, "Cytotoxic effect of Annona muricata Linn leaves extract on capan-1 cells," Journal of Applied Pharmaceutical Science, vol. 5, no. 5, pp. 045-048, 2015.

[83] L. A. Betancur-Galvis, J. Saez, H. Granados, A. Salazar, and J. E. Ossa, "Antitumor and antiviral activity of Colombian medicinal plant extracts," Memórias do Instituto Oswaldo Cruz, vol. 94, no. 4, pp. 531-535, 1999.

[84] A. Quispe, D. Zavala, J. Rojas, M. Posso, and A. Vaisberg, "Efecto citotóxico selectivo in vitro de muricin $\mathrm{H}$ (acetogenina de Annona muricata) en cultivos celulares de cáncer de pulmón," Revista Peruana de Medicina Experimental y Salud Publica, vol. 23, pp. 265-269, 2006.

[85] H. Ménan, J.-T. Banzouzi, A. Hocquette et al., "Antiplasmodial activity and cytotoxicity of plants used in west African traditional medicine for the treatment of malaria," Journal of Ethnopharmacology, vol. 105, no. 1-2, pp. 131-136, 2006.

[86] E. Osorio, G. J. Arango, N. Jiménez et al., "Antiprotozoal and cytotoxic activities in vitro of Colombian Annonaceae," Journal of Ethnopharmacology, vol. 111, no. 3, pp. 630-635, 2007.

[87] M. Nawwar, N. Ayoub, S. Hussein et al., "Flavonol triglycoside and investigation of the antioxidant and cell stimulating activities of Annona muricata Linn," Archives of Pharmaceutical Research, vol. 35, no. 5, pp. 761-767, 2012.

[88] Y. Gavamukulya, F. Abou-Elella, F. Wamunyokoli, and H. AEl-Shemy, "Phytochemical screening, anti-oxidant activity and in vitro anticancer potential of ethanolic and water leaves extracts of Annona muricata (Graviola)," Asian Pacific Journal of Tropical Medicine, vol. 7, pp. S355-S363, 2014.

[89] Y. Dai, S. Hogan, E. M. Schmelz et al., "Selective growth inhibition of human breast cancer cells by graviola fruit extract in vitro and in vivo involving downregulation of EGFR expression," Nutrition and Cancer, vol. 63, no. 5, pp. 795-801, 2011.

[90] S. Slezakova and J. Ruda-Kucerova, "Anticancer activity of artemisinin and its derivatives," Anticancer Research, vol. 37, no. 11, pp. 5995-6003, 2017.

[91] S. J. Langa, M. Schmiecha, S. Hafnera et al., "Antitumor activity of an Artemisia annua herbal preparation and identification of active ingredients," Phytomedicine, vol. 62, Article ID 152962, 2019.

[92] G. Isani, M. Bertocchi, G. Andreani et al., "Cytotoxic effects of Artemisia Annua L. and pure artemisinin on the D-17 canine osteosarcoma cell line," Oxidative Medicine and Cellular Longevity, vol. 2019, Article ID 1615758, 9 pages, 2019.

[93] T. Omara, R. Nnankabirwa, W. Nassazi, B. V. Nakabuye, and B. Musau, "Spectroscopic screening of assorted pigmented vegetables and fruits common in metropolitan Kampala culinary recipes for anthocyanins," International Journal of Food Science and Nutrition, vol. 3, no. 6, pp. 285-290, 2018.

[94] H. S. El-Beltagi, H. I. Mohamed, B. M. H. Megahed, M. Gamal, and G. Safwat, "Evaluation of some chemical constituents, antioxidant, antibacterial and anticancer activities of Beta vulgaris L. root," Fresenius Environmental Bulletin, vol. 27, no. 9, pp. 6369-6378, 2018.

[95] G. J. Kapadia, M. A. Azuine, G. S. Rao, T. Arai, A. Iida, and H. Tokuda, "Cytotoxic effect of the red beetroot (Beta vulgaris L.) extract compared to doxorubicin (adriamycin) in the human prostate (PC-3) and breast (MCF-7) cancer cell lines," Anti-cancer Agents in Medicinal Chemistry, vol. 11, no. 3, 2011. 
[96] B. K. Langat, L. L. Asaava, and J. O. Midiwo, "In vitro and in vivo antiplasmodial activity of Kenyan medicinal plants," in Aspects of African Biodiversity, Proceedings of the Pan-Africa Chemistry Network, J. O. Midiwo and J. Clough, Eds., pp. 20-28, RCS Publishing, Cambridge, UK, 2010.

[97] D. Z. Matata, O. D. Ngassapa, F. Machumi, and M. J. Moshi, "Screening of plants used as traditional anticancer remedies in mkuranga and same districts, Tanzania, using brine shrimp toxicity bioassay," Evidence-Based Complementary and Alternative Medicine, vol. 2018, Article ID 3034612, 16 pages, 2018.

[98] W. A. Devane, L. Hanus, A. Breuer et al., "Isolation and structure of a brain constituent that binds to the cannabinoid receptor," Science, vol. 258, no. 5090, pp. 1946-1949, 1992.

[99] G. Velasco, C. Sanchez, and M. Guzman, "Towards the use of cannabinoids as antitumour agents," Natural Reviews Cancer, vol. 12, no. 6, pp. 436-444, 2012.

[100] A. L. Tariq and A. L. Reyaz, "Isolation of cannabinoids from the plant Cannabis sativa and its potential anticancer activity," International Journal of Drug Development and Research, vol. 4, no. 1, pp. 241-246, 2012.

[101] S. Yousuf, R. S. Kamdem, P. Wafo, B. T. Ngadjui, and H. K. Fun, "3a-Hydroxytirucalla-8, 24-dien-21-oic acid," Acta Crystallographica Section E, vol. E67, no. 4, pp. o937o938, 2011.

[102] C. Orwa, A. Mutua, R. Kindt, R. Jamnadass, and A. Simons, "Agroforestree database: a tree reference and selection guide version 4.0," 2009, http://www.worldagroforestry.org/af/ treedb/.

[103] T. Helen, F. Serge, B. T. Ngadjui, D. Etienne, and B. M. Abegaz, "Phenolic metabolites from seeds of Canarium schweinfurthii," Bulletin of the Chemical Society of Ethiopia, vol. 14, no. 2, pp. 155-160, 2000.

[104] S. E. Atawodi, "Polyphenol composition and in vitro antioxidant potential of Nigerian Canarium schweinfurthii engl oil," Advances in Biological Research, vol. 4, no. 6, pp. 314322, 2010.

[105] G. A. Shaimaa, M. S. Mahmoud, M. R. Mohamed, and A. A. Emam, "Phytochemical screening, antioxidant activities and in vitro anticancer potential of Egyptian capsicum spp," Biochemistry \& Pharmacology, vol. 5, no. 2, p. 1000205 , 2016.

[106] W.-C. Teng, W. Chan, R. Suwanarusk et al., "In vitro antimalarial evaluations and cytotoxicity investigations of Carica papaya leaves and carpaine," Natural Products Communication, vol. 14, no. 1, pp. 33-36, 2019.

[107] P. Melariri, W. Campbell, P. Etusim, and P. Smith, "Antiplasmodial properties and bioassay-guided fractionation of ethyl acetate extracts from Carica papaya leaves," Journal of Parasitology Research, vol. 2011, Article ID 104954, 7 pages, 2011.

[108] A. Rahmat, R. Rosli, S. Endrini, W. N. I. W. M. Zain, S. Edrinin, and H. A. Sani, "Antiproliferative activity of pure lycopene compared to both extracted lycopene and juices from watermelon (Citrullus vulgaris) and papaya (Carica papaya) on human breast and liver cancer cell lines," Journal of Medical Sciences, vol. 2, no. 2, pp. 55-58, 2002.

[109] Y. Nakamura, M. Yoshimoto, Y. Murata et al., "Papaya seed represents a rich source of biologically active isothiocyanate," Journal of Agricultural and Food Chemistry, vol. 55, no. 11, pp. 4407-4413, 2007.

[110] P. Garcia-Solis, E. M. Yahia, V. Morales-Tlalpan, and M. Diaz-Munoz, "Screening of antiproliferative effect of aqueous extracts of plant foods consumed in Mexico on the breast cancer cell line MCF-7," International Journal of Food Sciences and Nutrition, vol. 60, no. 6, pp. 32-46, 2009.

[111] R. Jayakumar and M. S. Kanthimathi, "Inhibitory effects of fruit extracts on nitric oxide-induced proliferation in MCF-7 cells," Food Chemistry, vol. 126, no. 3, pp. 956-960, 2011.

[112] M. Hirose, T. Yamaguchi, N. Kimoto et al., "Strong promoting activity of phenylethyl isothiocyanate and benzyl isothiocyanate on urinary bladder carcinogenesis in F344 male rats," International Journal of Cancer, vol. 77, no. 5, pp. 773-777, 1998.

[113] C. Morimoto, N. H. Dang, and N. Dang, "Cancer prevention and treating composition for preventing, ameliorating, or treating solid cancers, e.g. lung, or blood cancers, e.g. lymphoma, comprises components extracted from brewing papaya," Patent WO2006004226-A1, EP1778262 A1, JP2008505887-W, US2008069907-A1, YS Therapeutic Co Ltd. (YSTH-Non-Standard) Toudai Tlo Ltd. (TODNonStandard), 2008.

[114] N. Otsuki, N. H. Dang, E. M. I. Kumagai et al., "Aqueous extract of Carica papaya leaves exhibits anti-tumour activity and immunomodulatory effects," Journal of Ethnopharmacology, vol. 127, no. 3, pp. 760-767, 2010.

[115] T. T. Nguyen, M.-O. Parat, P. N. Shaw, A. K. Hewavitharana, and M. P. Hodson, "Traditional aboriginal preparation alters the chemical profile of Carica papaya leaves and impacts on cytotoxicity towards human squamous cell carcinoma," PLoS One, vol. 11, no. 2, Article ID e0147956, 2016.

[116] N. R. Mustafa and R. Verpoorte, "Phenolic compounds in Catharanthus roseus," Phytochemistry Reviews, vol. 6, no. 23, pp. 243-258, 2007.

[117] S. Hisiger and M. Jolicoeur, "Analysis of Catharanthus roseus alkaloids by HPLC," Phytochemistry Reviews, vol. 6, no. 2-3, pp. 207-234, 2007.

[118] J. Y. Ueda, Y. Tezuka, A. H. Banskota et al., "Antiproliferative activity of Vietnamese medicinal plants," Biological and Pharmaceutical Bulletin, vol. 25, no. 6, pp. 753-760, 2002.

[119] K. Hostettmann, A. Marston, K. Ndjoko, and J.-L. Wolfender, "The potential of African plants as a source of drugs," Current Organic Chemistry, vol. 4, no. 10, pp. 973-1010, 2000.

[120] M. J. Siddiqui, Z. Ismail, A. F. A. Aisha, and A. M. S. Abdul Majid, "Cytotoxic activity of Catharanthus roseus (Apocynaceae) crude extracts and pure compounds against human colorectal carcinoma cell line," International Journal of Pharmacology, vol. 6, no. 1, pp. 43-47, 2010.

[121] A. T. Khalil, G. T. Maatooq, and K. A. El Sayed, "Limonoids from Citrus reticulata," Zeitschrift Für Naturforschung C, vol. 58, no. 3-4, pp. 165-170, 2003.

[122] Y. Wang, J. Qian, J. Cao et al., “Antioxidant capacity, anticancer ability and flavonoids composition of 35 citrus (citrus reticulata blanco) varieties," Molecules, vol. 22, p. $1114,2017$.

[123] E. Chrisnanto, R. Adelina, P. P. D. Dewi et al., "Antiangiogenic effect of ethanol extract of citrus reticulata peel in the chorio allantoic membrane (CAM) induced by bFGF," in Proceedings of the Molecular Targeted Therapy Symposium, Yogyakarta, Indonesia, pp. 57-66, 2008.

[124] L. T. Bidinotto, A. R. A. C. Celso, M. F. S. Daisy et al., "Protective Effects of lemon grass (Cymbopogon citratus STAPF) essential oil on DNA damage and carcinogenesis in female Balb/C mice," Journal of Applied Toxicology, vol. 31, no. 6, pp. 536-544, 2011.

[125] F. Tchoumbougnang, P. H. A. Zollo, E. Dagne, and Y. Mekonnen, "In vivo antimalarial activity of essential oils 
from Cymbopogon citratus and Ocimum gratissimum on mice infected with Plasmodium berghei," Planta Medica, vol. 71, no. 1, pp. 20-33, 2005.

[126] R. A. Zeinab, M. Mroueh, M. Diab-Assaf et al., "Chemopreventive effects of wild carrot oil against 7,12-dimethyl benz(a)anthracene-induced squamous cell carcinoma in mice," Pharmaceutical Biology, vol. 49, no. 9, pp. 955-961, 2011.

[127] W. N. Shebaby, C. F. Daher, M. El-Sibai et al., "Antioxidant and hepatoprotective activities of the oil fractions from wild carrot (Daucus carota ssp. carota)," Pharmaceutical Biology, vol. 53, no. 9, pp. 1285-1294, 2015.

[128] M. Mroueh, F. El Ghaziri, and C. Daher, "Prevention of carcinogen-induced mouse skin papilloma by Daucus carota (wild carrot) aqueous extract," Planta Medica, vol. 77, no. 12, 2011.

[129] W. N. Shebaby, M. Mroueh, K. Bodman-Smith et al., "Daucus carota pentane-based fractions arrest the cell cycle and increase apoptosis in MDA-MB-231 breast cancer cells," BMC Complementary and Alternative Medicine, vol. 14, no. 1, 2014.

[130] M. K. Tsanuo, A. Hassanali, I. J. Jondiko, and B. Torto, "Mutangin, a dihydroagarofuranoid sesquiterpene insect antifeedant from Elaeodendron buchananii," Phytochemistry, vol. 34, no. 3, pp. 665-667, 1993.

[131] T. Yasuko, I. Jondiko, H. Tazaki, T. Fujimori, and K. Mori, "Buchaninoside, a steroidal glycoside from Elaeodendron buchananii," Phytochemistry, vol. 40, no. 3, pp. 753-756, 1995.

[132] I. Kubo and K. Fukuhara, "A new cytotoxic triterpene from an East African medicinal plant, Elaeodendron buchananii," Journal of Natural Products, vol. 53, no. 4, pp. 968-971, 1990.

[133] M. M. D. Mohammed, N. A. Ibrahim, N. E. Awad et al., "Anti-HIV-1 and cytotoxicity of the alkaloids of Erythrina abyssinica Lam. growing in Sudan," Natural Product Research, vol. 26, pp. 1565-1575, 2012.

[134] M. J. Moshi, Z. H. Mbwambo, M. C. Kapingu, V. H. Mhozya, and C. Marwa, "Evaluation of ethnomedical claims and brine shrimp toxicity of some plants used in Tanzania as traditional medicines," African Journal of Traditional, Complementary and Alternative Medicines, vol. 3, no. 3, pp. 48-58, 2006.

[135] N. Kishore, B. Binneman, A. Mahapatra et al., "Cytotoxicity of synthesized 1,4-naphthoquinone analogues on selected human cancer cell lines," Bioorganic \& Medicinal Chemistry, vol. 22, no. 17, pp. 5013-5019, 2014.

[136] M. H. Lopes and I. M. Paul, "Triterpenóides pentacíclicos de Euclea natalensis e Euclea divinorum," Revista Portuguesa de Química, vol. 15, pp. 213-217, 1973.

[137] N. Lall, O. Weiganand, A. A. Hussein, and J. J. M. Meyer, "Antifungal activity of naphthoquinones and triterpenes isolated from the root bark of Euclea natalensis," South African Journal of Botany, vol. 72, no. 4, pp. 579-583, 2006.

[138] M. Moshi, C. J. Van den Beukel, O. J. M. Hamza et al., "Brine shrimp toxicity evaluation of some Tanzanian plants used traditionally for the treatment of fungal infections," African Journal of Traditional, Complementary and Alternative Medicines, vol. 4, no. 2, pp. 219-225, 2008.

[139] N. Lall, J. J. M. Meyer, Y. Wang et al., "Characterization of intracellular activity of antitubercular constituents from the roots of Euclea natalensis," Pharmaceutical Biology, vol. 43, no. 4, pp. 353-357, 2005.

[140] E. Chivandi, E. Cave, B. C. Davidson et al., "Suppression of Caco-2 and HEK-293 cell proliferation by Kigelia africana,
Mimusops zeyheri and Ximenia caffra seed oils," In Vivo, vol. 26, no. 1, pp. 99-105, 2012.

[141] T. Guon and H.-S. Chung, "Induction of apoptosis with Kigelia africana fruits in HCT116 human colon cancer cells via MAPKs signaling pathway," Natural Product Sciences, vol. 22, no. 3, pp. 209-215, 2016.

[142] D. Lacroix, S. Prado, D. Kamoga et al., "Antiplasmodial and cytotoxic activities of medicinal plants traditionally used in the village of Kiohima, Uganda," Journal of Ethnopharmacology, vol. 133, pp. 850-855, 2011.

[143] N. Rajendran, R. Ananthathamula, K. P. Arun, and P. Brindha, "Anticancer and antioxidant activity of ethanolic extract of Markhamia lutea (Benth) K. schum stem bark," Asian Journal of Chemistry, vol. 26, no. 12, pp. 3741-3744, 2014.

[144] D. Lacroix, S. Prado, A. Deville et al., "Hydroperoxycycloartane triterpenoids from the leaves of Markhamia lutea, a plant ingested by wild chimpanzees," Phytochemistry, vol. 70, no. 10, pp. 1239-1245, 2009.

[145] H. Kaur and Shantanu, "Anticancer activity of a constituent from Moringa oleifera leaves," Journal of Chemical and Pharmaceutical Research, vol. 7, no. 1, pp. 701-705, 2015.

[146] A. K. Al-Asmari, S. M. Albalawi, M. T. Athar, A. Q. Khan, H. Al-Shahrani, and M. Islam, "Moringa oleifera as an anticancer agent against breast and colorectal cancer cell lines," PLoS One, vol. 10, no. 8, Article ID e0135814, 2015.

[147] M. V. S. Parvathy and A. Umamaheshwari, "Cytotoxic effect of Moringa oleifera leaf extracts on human multiple myeloma cell lines," Trends in Medical Research, vol. 2, no. 1, pp. 44-50, 2007.

[148] K. Varalakshmi and S. Nair, "Anticancer, cytotoxic potential of Moringa oleifera extracts on HeLa cell line," Journal of Natural Pharmaceuticals, vol. 2, no. 3, p. 138, 2011.

[149] T. Milugo, V. M. Masila, B. Owuor et al., "Anti-cancer activities of crude extracts from medicinal plants Moringa oleifera Lam and Rauwolfia caffra against selected cancer cell lines," IOSR Journal of Pharmacy and Biological Sciences, vol. 11, no. 3, pp. 59-64, 2016.

[150] M. D. M. Zayas-Viera, P. E. Vivas-Mejia, and J. Reyes, "Anticancer effect of Moringa oleifera leaf extract in human cancer cell lines," Journal of Health Disparities Research and Practice, vol. 9, no. 1, 2016.

[151] C. Suphachai, "Antioxidant and anticancer activities of Moringa oleifera leaves," Journal of Medicinal Plants Research, vol. 8, no. 7, pp. 318-325, 2014.

[152] M. M. Khalafalla, E. Abdellatef, H. M. Dafalla et al., "Active principle from Moringa oleifera Lam leaves effective against two leukemias and a hepatocarcinoma," African Journal of Biotechnology, vol. 9, no. 49, pp. 8467-8471, 2010.

[153] I. L. Jung, J. H. Lee, and S. C. Kang, "A potential oral anticancer drug candidate, Moringa oleifera leaf extract, induces the apoptosis of human hepatocellular carcinoma cells," Oncology Letters, vol. 10, no. 3, pp. 1597-1604, 2015.

[154] P. T. Krishnamurthy, A. Vardarajalu, A. Wadhwani, and V. Patel, "Identification and characterization of a potent anticancer fraction from the leaf extracts of Moringa oleifera L," Indian Journal of Experimental Biology, vol. 53, no. 2, pp. 98-103, 2015

[155] C. Tiloke, A. Phulukdaree, and A. A. Chuturgoon, "The antiproliferative effect of Moringa oleifera crude aqueous leaf extract on cancerous human alveolar epithelial cells," BMC Complementary and Alternative Medicine, vol. 13, no. 1, p. 8, 2013. 
[156] N. Madi, M. Dany, S. Abdoun, and J. Usta, "Moringa oleifera's nutritious aqueous leaf extract has anticancerous effects by compromising mitochondrial viability in an ROSdependent manner," Journal of the American College of Nutrition, vol. 35, no. 7, pp. 604-613, 2016.

[157] L. Berkovich, G. Earon, I. Ron, A. Rimmon, A. Vexler, and S. Lev-Ari, "Moringa Oleifera aqueous leaf extract downregulates nuclear factor- $\kappa \mathrm{B}$ and increases cytotoxic effect of chemotherapy in pancreatic cancer cells," BMC Complementary and Alternative Medicine, vol. 13, no. 1, p. 7, 2013.

[158] A. S. Rajesh, N. S. S. Kiran, P. C. Tripathi, and K. Verma, "In vitro cytotoxicity of Moringa oleifera against different human cancer cell lines," Asian Journal of Pharmaceutical and Clinical Research, vol. 5, no. 4, pp. 271-272, 2012.

[159] A. P. Guevara, C. Vargas, H. Sakurai et al., "An antitumor promoter from Moringa oleifera Lam," Mutation Research, vol. 440, no. 2, pp. 181-188, 1999.

[160] J. O. Kuti, "Antioxidant compounds from four Opuntia cactus pear fruit varieties," Food Chemistry, vol. 85, no. 4, pp. 527-533, 2004.

[161] R. A. Chavez-Santoscoy, J. A. Gutierrez-Uribe, and S. O. Serna-Saldívar, "Phenolic composition, antioxidant capacity and in vitro cancer cell cytotoxicity of nine prickly pear (Opuntia spp.) juices," Plant Foods for Human Nutrition, vol. 64, no. 2, pp. 146-152, 2009.

[162] M. Antunes-Ricardo, B. E. Moreno-García, J. A. GutiérrezUribe, D. Aráiz-Hernández, M. M. Alvarez, and S. O. SernaSaldivar, "Induction of apoptosis in colon cancer cells treated with isorhamnetin glycosides from Opuntia ficusindica pads," Plant Foods for Human Nutrition, vol. 69, no. 4, pp. 331-336, 2014.

[163] D. Sreekanth, M. K. Arunasree, K. R. Roy, T. Chandramohan Reddy, G. V. Reddy, and P. Reddanna, "Betanin a betacyanin pigment purified from fruits of Opuntia ficus-indica induces apoptosis in human chronic myeloid leukemia cell lineK562," Phytomedicine, vol. 14, no. 11, pp. 739-746, 2007.

[164] S.-W. Hahm, J. Park, S.-Y. Oh et al., "Anticancer properties of extracts from Opuntia humifusa against human cervical carcinoma cells," Journal of Medicinal Food, vol. 18, no. 1, pp. 31-44, 2015.

[165] M. Srikanth, S. Tadigotla, and B. Veeresh, "Phytochemistry and pharmacology of Oxalis corniculata linn: a review," International Journal of Pharmaceutical Sciences and Research, vol. 3, no. 11, pp. 4077-4085, 2012.

[166] A. Kathiriya, K. Das, E. P. Kumar, and K. B. Mathai, "Evaluation of antitumor and antioxidant activity of Oxalis corniculata linn. against ehrlich ascites carcinoma on mice," Iranian Journal of Cancer Prevention, vol. 3, no. 4, pp. 157-165, 2010.

[167] M. C. Ngule, M. H. Ndiku, and F. Ramesh, "Chemical constituents screening and in vitro antibacterial assessment of Prunus africana bark hydromethanolic extract," Journal of Natural Sciences Research, vol. 4, no. 16, pp. 85-90, 2014.

[168] A. K. Jena, K. Vasisht, N. Sharma et al., "Amelioration of testosterone induced benign prostatic hyperplasia by Prunus species," Journal of Ethnopharmacology, vol. 190, pp. 33-45, 2016.

[169] D. W. Nyamai, A. M. Mawia, F. K. Wanbua et al., "Phytochemical profile of Prunus africana stem bark from Kenya," Journal of Pharmacognosy and Natural Products, vol. 1, no. 110, p. 8, 2015.

[170] D. O. Ochwang'i, C. N. Kimwele, J. A. Oduma et al., "Medicinal plants used in treatment and management of cancer in Kakamega County, Kenya," Journal of Ethnopharmacology, vol. 151, no. 3, pp. 1040-1055, 2014.

[171] S. M. A. Margalef, P. R. Barzanti, R. J. Puigjaner, R. J. Morote, and T. T. M. Okatsu, "Antimitogenic effect of Pygeum africanum extracts on human prostatic cancer cell lines and explants from benign prostatic hyperplasia," Archivos Españoles de Urología, vol. 56, no. 4, pp. 369-378, 2003

[172] L. K. Omosa, G. M. Mbogo, E. Korir et al., "Cytotoxicity of fagaramide derivative and canthin-6-one from Zanthoxylum (Rutaceae) species against multidrug resistant leukemia cells," Natural Product Research, pp. 1-8, 2019.

[173] M. Chrian, P. Erasto, and N. J. Otieno, "Antimycobacterial activity and cytotoxicity effect of extracts of Hallea rubrostipulata and Zanthoxylum chalybeum," Spatula DD, vol. 1, no. 3, pp. 147-152, 2011.

[174] E. Nibret, M. L. Ashour, C. D. Rubanza, and M. Wink, "Screening of some Tanzanian medicinal plants for their trypanocidal and cytotoxic activities," Phytotherapy Research, vol. 24, pp. 945-947, 2010.

[175] F. Ocheng, F. Bwanga, E. A. Boström et al., "Essential oils from Ugandan medicinal plants: in vitro cytotoxicity and effects on IL- $1 \beta$-induced proinflammatory mediators by human gingival fibroblasts," Evidence-Based Complementary and Alternative Medicine, vol. 2016, Article ID 5357689, 8 pages, 2016.

[176] M. M. Kaigongi, S. F. Dossaji, J. M. Nguta, C. W. Lukhoba, and F. M. Musila, "Antimicrobial activity, toxicity and phytochemical screening of four medicinal plants traditionally used in Msambweni District, Kenya," Journal of Biology, Agriculture and Healthcare, vol. 4, p. 28, 2014.

[177] T. K. Lim, "Abelmoschus esculentus," in Edible Medicinal and Non-Medicinal Plants, vol. 3, pp. 160-167, Springer, Dordrecht, Netherlands, 2012.

[178] V. Sabitha, S. Ramachandran, K. R. Naveen, and K. Panneerselvam, "Investigation of in vivo antioxidant property of Abelmoschus esculentus (L) moench. fruit seed and peel powders in streptozotocin-induced diabetic rats," Journal of Ayurveda and Integrative Medicine, vol. 3, no. 4, pp. 188-193, 2012.

[179] J. Namukobe, J. M. Kasenene, B. T. Kiremire et al., "Traditional plants used for medicinal purposes by local communities around the northern sector of Kibale National Park, Uganda," Journal of Ethnopharmacology, vol. 136, no. 1, pp. 236-245, 2011.

[180] J. Bindu and R. T. Narendhirakannan, "Role of medicinal plants in the management of diabetes mellitus: a review," Biotechnology, vol. 9, no. 1, p. 4, 2019.

[181] G. Kaur, R. Padiya, R. Adela et al., "Garlic and resveratrol attenuate diabetic complications, loss of $\beta$-cells, pancreatic and hepatic oxidative stress in streptozotocin-induced diabetic rats," Frontiers in Pharmacology, vol. 7, p. 360, 2016.

[182] M. Joyeux, F. Mortier, and J. Fleurentin, "Screening of antiradical, antilipoperoxidant and hepatoprotective effects of nine plant extracts used in Caribbean folk medicine," Phytotherapy Research, vol. 9, no. 3, pp. 228-230, 1995.

[183] N. H. Oberlies, C.-J. Chang, and J. L. McLaughlin, "Structure-activity relationships of diverse annonaceous acetogenins against multidrug resistant human mammary adenocarcinoma (MCF7/Adr) cells," Journal of Medicinal Chemistry, vol. 40, no. 13, pp. 2102-2106, 1997.

[184] W. E. Ho, H. Y. Peh, T. K. Chan, and W. S. F. Wong, "Artemisinins: pharmacological actions beyond antimalarial," Pharmacology \& Therapeutics, vol. 142, no. 1, pp. 126-139, 2014. 
[185] M. M. Adia, G. Anywar, R. Byamukama et al., "Medicinal plants used in malaria treatment by Prometra herbalists in Uganda," Journal of Ethnopharmacology, vol. 155, no. 1, pp. 580-588, 2014.

[186] M. A. Sonibare, G. K. Oloyede, and T. F. Adaramola, "Antioxidant and cytotoxicity evaluations of two species of Blighia providing clues to species diversity," Electronic Journal of Environmental, Agricultural and Food Chemistry, vol. 10, no. 10, pp. 2960-2971, 2011.

[187] Daily Monitor, Benefits of Prickly Pear Cactus, 2017, https:// www.monitor.co.ug/Magazines/HealthLiving/Benefits-ofprickly-pear-cactsus/689846-3919426-ec0nw7/index.html.

[188] C. Gentile, L. Tesoriere, M. Allegra, M. A. Livrea, and P. D'Alessio, "Antioxidant betalains from cactus pear (Opuntia ficus-indica) inhibit endothelial ICAM-1 expression," Annals of the New York Academy of Sciences, vol. 1028, no. 1, pp. 481-486, 2004.

[189] R. G. Pertwee, "Cannabinoid receptors and pain," Journal of Prognosis and Neurobiology, vol. 63, no. 5, pp. 569-611, 2001.

[190] M. Ben Amar, "Cannabinoids in medicine: a review of their therapeutic potential," Journal of Ethnopharmacology, vol. 105, no. 1-2, pp. 1-25, 2006.

[191] R. G. Pertwee, A. C. Howlett, M. E. Abood et al., "International union of basic and clinical pharmacology, LXXIX, cannabinoid receptors and their ligands: beyond CB1 and CB2," Pharmacology Reviews, vol. 62, no. 4, pp. 588-631, 2010.

[192] K.-N. Ngbolua, G. N. Bongo, C. A. Masengo et al., "Ethnobotanical survey and ecological study of plants resources used in folk medicine to treat symptoms of tuberculosis in Kinshasa city, democratic republic of the Congo," Journal of Modern Drug Discovery and Drug Delivery Research, vol. 1, no. 3, pp. 1-6, 2014.

[193] V. Kuete, L. P. Sandjo, A. T. Mbaveng et al., "Cytotoxicity of selected Cameroonian medicinal plants and Nauclea pobeguinii towards multi-factorial drug-resistant cancer cells," BMC Complementary and Alternative Medicine, vol. 15, no. 1, p. 9, 2015.

[194] L. C. Obame, J. Koudou, B. S. Kumulungui et al., "Antioxidant and antimicrobial activities of Canarium schweinfurthii Engl. essential oil from Central African Republic," African Journal of Biotechnology, vol. 6, no. 20, pp. 23192323, 2007.

[195] P. M. J. Dongmo, F. Tchoumbougnang, B. Ndongson et al., "Chemical characterization, antiradical, antioxidant and anti-inflammatory potential of the essential oils of Canarium schweinfurthii and Aucoumea klaineana (Burseraceae) growing in Cameroon," Agriculture and Biology Journal of North America, vol. 1, no. 4, pp. 606-611, 2010.

[196] B. Morris, "Chewa medical botany," in Monographs from the International African Institute, Vol. 2, Lit-Verlag, Hamburg, Germany, 1996.

[197] G. Anywar, C. I. E. A. van't Klooster, R. Byamukama et al., "Medicinal plants used in the treatment and prevention of malaria in cegere sub-county, Northern Uganda," Ethnobotany Research and Applications, vol. 14, pp. 505-516, 2016.

[198] M. Lamorde, J. R. S. Tabuti, C. Obua et al., "Medicinal plants used by traditional medicine practitioners for the treatment of HIV/AIDS and related conditions in Uganda," Journal of Ethnopharmacology, vol. 130, no. 1, pp. 43-53, 2010.

[199] C. Oryema, R. B. Ziraba, N. Omagor, and A. Opio, "Medicinal plants of Erute county, Lira district, Uganda with particular reference to their conservation," African Journal of Ecology, vol. 48, no. 2, pp. 285-298, 2010.
[200] T. Johns, J. O. Kokwaro, and E. K. Kimanani, "Herbal remedies of the Luo of siaya district, Kenya: establishing quantitative criteria for consensus," Economie Botany, vol. 44, no. 3, pp. 369-381, 1990.

[201] A. C. Emeruwa, "Antibacterial substance from Carica papaya fruit extract," Journal of Natural Products, vol. 45, no. 2, pp. 123-127, 1982.

[202] J. Okello and P. Ssegawa, "Medicinal plants used by communities of ngai subcounty, Apac district, northern Uganda," African Journal of Ecology, vol. 45, no. 1, pp. 76-83, 2007.

[203] P. W. Bosland and E. J. Votava, Peppers: Vegetable and Spice Capsicums, CABI Publishing, Wallingford, UK, 2000.

[204] M. S. Islam and H. Choi, "Dietary red chilli (Capsicum frutescens L.) is insulinotropic rather than hypoglycemic in type 2 diabetes model of rats," Phytotherapy Research, vol. 22, no. 8, pp. 1025-1029, 2008.

[205] J. A. Duke, Handbook of Medicinal Herbs: Catharanthus Roseus, CRC Press, Boca Raton, FL, USA, 1985.

[206] O. P. Virmani, G. N. Srivastava, and P. Singh, "Catharanthus roseus the tropical periwinkle," Indian Drugs, vol. 15, pp. 231-252, 1978.

[207] K. Sukumar and Z. Osmani, "Insect sterilants from Catharanthus roseus," Current Science, vol. 50, no. 12, pp. 552-553, 1981.

[208] D. M. Pereira, F. Ferreres, J. Oliveira et al., "Targeted metabolite analysis of Catharanthus roseus and its biological potential," Food and Chemical Toxicology, vol. 47, no. 6, pp. 1349-1354, 2009.

[209] Y. Kumarasamy, L. Nahar, M. Byres, A. Delazar, and S. D. Sarker, "The assessment of biological activities associated with the major constituents of the methanol extract of "wild carrot" (Daucus carota L) seeds," Journal of Herb Pharmacotherapy, vol. 5, no. 1, pp. 61-72, 2005.

[210] J. O. Kokwaro, Medicinal Plants of East Africa, East African Literature Bureau, Nairobi, Kenya, 2nd edition, 1993.

[211] D. K. B. Runyoro, M. I. N. Matee, O. D. Ngassapa, C. J. Cosam, and Z. H. Mbwambo, "Screening of Tanzanian medicinal plants for anti-candida activity," BMC Complementary and Alternative Medicine, vol. 6, no. 1, p. 10, 2006.

[212] E. O. Omwenga, A. Hensel, A. Shitandi, and F. M. Goycoole, "Ethnobotanical survey of traditionally used medicinal plants for infections of skin, gastrointestinal tract, urinary tract and the oral cavity in Borabu sub-county, Nyamira county, Kenya," Journal of Ethnopharmacology, vol. 176, pp. 508-514, 2015.

[213] B.-E. VanWyk, "The potential of South African plants in the development of new food and beverage products," South African Journal of Botany, vol. 77, no. 4, pp. 812-829, 2011.

[214] B.-E. van Wyk, "A broad review of commercially important southern African medicinal plants," Journal of Ethnopharmacology, vol. 119, no. 3, pp. 342-355, 2008.

[215] C. Clarkson, V. J. Maharaj, N. R. Crouch et al., "In vitro antiplasmodial activity of medicinal plants native to or naturalised in South Africa," Journal of Ethnopharmacology, vol. 92, no. 2-3, pp. 177-191, 2004.

[216] New Vision, The Sausage Tree: A Flower That Heals Ailments, 2019, https://www.newvision.co.ug/new_vision/ news/1493845/sausage-tree-flower-heals-ailments.

[217] A. K. Nyarko, L. K. N. Okine, R. K. Wedzi, P. A. Addo, and $\mathrm{M}$. Ofosuhene, "Sub-chronic toxicity studies of the antidiabetic herbal preparation ADD-199 in the rat: absence of 
organ toxicity and modulation of cytochrome P450," Journal of Ethnopharmacology, vol. 97, no. 2, pp. 319-325, 2005.

[218] S. V. Okello, R. O. Nyunja, G. W. Netondo, and J. C. Onyango, "Ethnobotanical study of medicinal plants used by sabaots of Mt. Elgon Kenya," African Journal of Traditional, Complementary and Alternative Medicine, vol. 7, no. 1, pp. 1-10, 2010.

[219] P. Brindha, A. Ragamanvitha, S. Narendran, S. Sriram, and V. Vadivel, "Antioxidant activity and phytochemical composition of aqueous extract of Markhamia lutea (Benth) K. Schum. leaves," Tropical Journal of Natural Products Research, vol. 1, no. 2, pp. 63-68, 2017.

[220] F. Anwar, S. Latif, M. Ashraf, and A. H. Gilani, "Moringa oleifera: a food plant with multiple medicinal uses," Phytotherapy Research, vol. 21, no. 1, pp. 17-25, 2007.

[221] S. Sreelatha and P. R. Padma, "Antioxidant activity and total phenolic content of moringa oleifera leaves in two stages of maturity," Plant Foods for Human Nutrition, vol. 64, no. 4, pp. 303-311, 2009.

[222] A. P. Guevara, C. Vargas, and U. Y. Milagros, "Anti-inflammatory and antitumor activities of seed extracts of malunggay, Moringa Oleifera L. (Moringaceae)," Philippine Journal of Science, vol. 125, no. 3, pp. 175-184, 1996.

[223] L. Lagnika, A. M. O. Amoussa, S. A. Oketokoun, Y. Adjovi, and A. Sanni, "In vitro antifungal and antioxidant activities of two benin medicinal plants," Journal of Medicinal Plants Research, vol. 8, no. 12, pp. 513-519, 2014.

[224] S. M. Bach, E. P. Marina, P. M. Ana et al., "Chemical constituents, anti-inflammatory and antioxidant activities of bark extracts from Prunus tucumanensis Lillo," Natural Products Research, vol. 27, no. 10, pp. 1-4, 2003.

[225] A. N. Sawhney, M. R. Khan, G. Ndaalio, M. H. H. Nkunya, and S. H. Wever, "Studies on the rationale of African traditional medicine, part III, preliminary screening of medicinal plants for antifungal activity," Pakistan Journal of Science and Industrial Research, vol. 21, pp. 193-196, 1978.

[226] D. R. Opio, E. Andama, and G. T. Kureh, "Ethnobotanical survey of antimalarial plants in areas of: abukamola, angeta, oculokori and omarari of Alebtong district in northern Uganda," European Journal of Medicinal Plants, vol. 21, no. 4, pp. 1-14, 2018.

[227] J. R. S. Tabuti, L. A. Lye, and S. S. Dhillion, "Traditional herbal drugs of Bulamogi, Uganda: plants, use and administration," Journal of Ethnopharmacology, vol. 88, no. 1, pp. 19-44, 2003.

[228] J. W. Ogwal-Okeng, "Studies on the antimalarial activities of some Ugandan medicinal plants," Ph D dissertation, vol. 126, Faculty of Medicine, Makerere University, Kampala, Uganda, 1998.

[229] A. B. Katende, A. Birnie, and B. Tengnas, "Useful trees and shrubs of Uganda, regional soil conservation unit/SIDA," in Technical Handbook Series 10, SIDA, Nairobi, Kenya, 1995.

[230] R. Bukenya-Ziraba, P. Doenges, P. Duez, J. Lejoly, and J. Ogwal-Okeng, "Medicinal plants subsector review: pharmacopoeia promoting programme study," Final Report to Ministry of Health, Ministry of Health, Kampala, Uganda, 1997.

[231] S. Torunn, H. Wangensteen, E. Katuura, K. A. Lye, and S. P. Berit, "Antioxidant and anti-plasmodial activity of extracts from three Ugandan medicinal plants," Journal of Medicinal Plants Research, vol. 4, no. 18, pp. 1916-1923, 2010.

[232] D. Olila, Olwa-Odyek, and A. J. Opuda, "Antibacterial and antifungal activities of extracts of Zanthoxylum chalybeum and Warburgia ugandensis, Ugandan medicinal plants," African Health Sciences, vol. 1, no. 2, pp. 66-72, 2001.

[233] M. S. Agwaya, P. C. Vuzi, and A. M. Nandutu, "Hypoglycemic activity of aqueous root bark extract Zanthoxylum chalybeum in alloxan-induced diabetic rats," Journal of Diabetes Research, vol. 2016, Article ID 8727590, 5 pages, 2016.

[234] The EastAfrican, In Uganda, Doctors Believe they are Winning War on Cancer Despite Rising Numbers, 2019, https://www.theeastafrican.co.ke/scienceandhealth/Ugandawar-on-cancer/3073694-5231662-14qc0ot/index.html.

[235] R. Echodu, H. Edema, G. M. Malinga et al., "Is nodding syndrome in Northern Uganda linked to consumption of mycotoxin contaminated food grains?" BMC Research Notes, vol. 11, p. 678, 2018.

[236] G. D. Stoner, M. A. Morse, and G. J. Kelloff, "Perspectives in cancer chemoprevention," Environmental Health Perspectives, vol. 105, no. 4, pp. 945-954, 1997.

[237] S. De Flora and L. R. Ferguson, "Overview of mechanisms of cancer chemopreventive agents," Mutation Research, vol. 591, no. 1-2, pp. 8-15, 2005.

[238] T. T. Ayele, "A review on traditionally used medicinal plants/ herbs for cancer therapy in Ethiopia: current status, challenge and future perspectives," Organic Chemistry: Current Research, vol. 7, no. 2, p. 8, 2018.

[239] M. S. Abu-Darwish and T. Efferth, "Medicinal plants from near east for cancer therapy," Frontiers in Pharmacology, vol. 9, p. 56, 2018

[240] M. Bourhia, A. A. Shahat, O. M. Almarfadi et al., "Ethnopharmacological survey of herbal remedies used for the treatment of cancer in the greater casablanca-Morocco," Evidence-Based Complementary and Alternative Medicine, vol. 2019, Article ID 1613457, 9 pages, 2019.

[241] A. I. Kuruppu, P. Paranagama, and C. L. Goonasekara, "Medicinal plants commonly used against cancer in traditional medicine formulae in Sri Lanka," Saudi Pharmaceutical Journal, vol. 27, no. 4, pp. 565-573, 2019.

[242] J. M. Onyancha, N. K. Gikonyo, S. W. Wachira, and M. M. Gicheru, "An ethnobotanical survey of plants used for the treatment and management of cancer in Embu County, Kenya," Journal of Medicinal Plants Studies, vol. 7, no. 4, pp. 39-46, 2019.

[243] N. Tuasha, D. Seifu, E. Gadisa, B. Petros, and S. Oredsson, "Cytotoxicity of selected Ethiopian medicinal plants used in traditional breast cancer treatment against breast-derived cell lines," Journal of Medicinal Plants Research, vol. 13, no. 9, pp. 188-198, 2019.

[244] L. R. Ferguson, M. Philpott, and N. Karunasinghe, "Dietary cancer and prevention using antimutagens," Toxicology, vol. 198, no. 1-3, pp. 147-159, 2004.

[245] O. M. Grace, H. D. V. Prendergast, A. K. Jäger, and J. Van Staden, "Bark medicines used in traditional healthcare in KwaZulu-Natal, South Africa: an inventory," South African Journal of Botany, vol. 69, no. 3, pp. 301-363, 2003.

[246] A. Kumar, D. Patil, P. R. Rajamohanan, and A. Ahmad, "Isolation, purification and characterization of vinblastine and vincristine from endophytic fungus Fusarium oxysporum isolated from Catharanthus roseus," PLoS One, vol. 8, no. 9, Article ID e71805, 2013.

[247] A. T. Mbaveng, V. Kuete, and T. Efferth, "Potential of central, eastern and Western Africa medicinal plants for cancer therapy: spotlight on resistant cells and molecular targets," 'Frontiers in Pharmacology, vol. 8, p. 31, 2017. 
[248] P. J. D. Bouic and J. H. Lamprecht, "Plant sterols and sterolin: a review of their immune-modulating properties," Alternative Medicine Review, vol. 4, no. 3, pp. 170-177, 1999.

[249] W.-Y. Li, S.-W. Chan, D.-J. Guo, and P. H.-F. Yu, "Correlation between antioxidative power and anticancer activity in herbs from traditional Chinese medicine formulae with anticancer therapeutic effect," Pharmaceutical Biology, vol. 45, no. 7, pp. 541-546, 2007.

[250] T. Efferth, "From ancient herb to modern drug: Artemisia annua and artemisinin for cancer therapy," Seminars in Cancer Biology, vol. 46, pp. 65-83, 2017.

[251] A. Bhaw-Luximon and D. Jhurry, "Artemisinin and its derivatives in cancer therapy: status of progress, mechanism of action, and future perspectives," Cancer Chemotherapy and Pharmacology, vol. 79, no. 3, pp. 451-466, 2017.

[252] S. Nobili, D. Lippi, E. Witort et al., "Natural compounds for cancer treatment and prevention," Pharmacological Research, vol. 59, no. 6, pp. 365-378, 2009.

[253] M. A. Jordan and L. Wilson, "Microtubules as a target for anticancer drugs," Natural Reviews on Cancer, vol. 4, no. 4, pp. 253-265, 2004.

[254] K. Annan and R. Dickson, "Evaluation of wound healing actions of hoslundia opposita vahl, Anthocleista nobilis G. Don. and Balanites aegyptiaca L." Journal of Science and Technology, vol. 28, no. 2, pp. 26-35, 2008.

[255] R. J. Sherines and S. S Howard, "Male infertility," in Campbells Urology, J. H. Harrison, R. F. Gittes, A. D. Perlmutter et al., Eds., vol. 1p. 715, 4th edition, WB Saunders, Philadelphia, PA, USA, 1978.

[256] S. A. James, L. Bilbiss, and B. Y. Muhammad, "The effects of Catharanthus roseus (L) G. Don 1838 aqueous leaf extract on some liver enzymes, serum proteins and vital organs," Science World Journal, vol. 2, no. 1, pp. 5-9, 2007.

[257] D. Levêque and F. Jehl, "Molecular pharmacokinetics of Catharanthus (vinca) alkaloids," Journal of Clinical Pharmacology, vol. 47, no. 5, pp. 579-588, 2007. 